\title{
研究論文
}

\section{Wikipedia に学術文献の参照記述を追加する編集の特定手法 A Method to Identify the Edits Adding Bibliographic References to Wikipedia}

\author{
吉川 次郎 ${ }^{1 *}$, 高久 雅生 ${ }^{2}$, 芳鐘 冬樹 ${ }^{2}$ \\ Jiro KIKKAWA ${ }^{1 *}$, Masao TAKAKU², Fuyuki YOSHIKANE ${ }^{2}$ \\ 1 筑波大学大学院 図書館情報メディア研究科 \\ Graduate School of Library, Information and Media Studies, University of Tsukuba \\ 干 305-8550 茨城県つくば市春日 1-2 \\ E-mail: jiro@slis.tsukuba.ac.jp \\ 2 筑波大学 図書館情報メディア系 \\ Faculty of Library, Information and Media Science, University of Tsukuba \\ 干 305-8550 茨城県つくば市春日 1-2 \\ E-mail: masao@slis.tsukuba.ac.jp, fuyuki@slis.tsukuba.ac.jp \\ *連絡先著者 Corresponding Author
}

Wikipedia 上での学術文献の参照記述の追加という事象を明らかにするための前提となる方法論として, 参照記述の初出時点を特定するための手法を提案し，評価実験を行った，提案手法は，まず，参照記述の 参照先を判定し，ページ情報，文献タイトル，識別子を取得する，次に，対象のページの全編集履歴およ びページ本文に対して識別子または文献タイトルを用いた手法を適用し，複数の初出時点候補を取得する. 最後に，候補から編集日時が最古のものを選択する．英語版の DOI リンクの初出時点データセットを基に 評価実験を行った結果，精度は全体で $93.3 \% ， 22$ 分野中 20 分野で $90 \%$ 以上であり，研究分野を問わず概ね 高い精度で参照記述の初出時点を特定できる手法であることが明らかになった.

We proposed a method to identify the edits adding bibliographic references to Wikipedia. The proposed method consists of the following steps. (1) The method extracts the references and matches them to a bibliographic database to build the basic data set. (2) It obtains the full revision history of the page that includes the references from dump data of Wikipedia. It also extracts identifiers and titles for each reference from the basic data set. (3) The method gets the candidate edits adding the references by using the ways, which use either identifiers or titles. (4) The method selects the oldest one as the edit adding the reference. We evaluated the proposed method by using the data set based on DOI links referenced on English Wikipedia. As a result, the accuracy was $93.3 \%$ as a whole and over $90 \%$ in 20 out of 22 research fields. We showed that the proposed method was able to identify the edits adding bibliographic references at a high accuracy regardless of research fields.

キーワード： Wikipedia，Digital Object Identifier (DOI)，学術情報流通

Keywords: Wikipedia, Digital Object Identifier (DOI), Scholarly Communication

\section{1.はじめに}

学術情報流通の電子化を背景に, ウェブ上で学術 文献が大規模に参照され，流通している。 ウェブを 通じた学術情報基盤が整備され，普及することによ り，従来の学術文献の利用者である研究者や専門家 などに限らず，様々な人々やコミュニティによる学
術文献の利活用が生じると考えられる。そのひとつ に, Wikipedia からの学術文献へのアクセスが挙げ られる。実際に，DOI (Digital Object Identifier, デジタルオブジェクト識別子) の世界最大規模の登 録機関である Crossref の 2015 年時点での報告 [I] によると, Web of Science や Scopus などの学術文 献データベースに次いで 5 番目にアクセスの多い参 
照元は Wikipedia であり，1 日あたり 2.5 万から 3 万件ほどのアクセスがある.

Wikipedia は誰でも編集できるフリーのオンライ ン百科事典であり, 学術的な内容を含む様々なペー ジが存在する，最大規模の言語版である英語版には 2018 年 12 月時点で 577 万件のページがあり，1ヶ月 あたり 74 億件のアクセスがある [2]. また, Alexa Internetによると, Google, YouTube, Facebook, Baidu に次いで 5 番目にアクセスが多く [3]，世界 で最も閲覧・利用されているウェブサイトのひとつ であるが，不特定多数の協㗢を通じて編纂されると いう性質上，内容がどれくらい正確で信頼できるか には設立初期から多くの批判や議論がある [4, 可].

より良質な百科事典を目指すために，Wikipedia では内容に関する三大方針として,「検証可能性」, 「中立的な観点」,「独自研究は載せない」がある。学 術文献が出典や情報源として示されるのは，これら の方針と相性が良く，コンテンツの質を間接的に担 保・向上しうるためである。すすおわ，学術文献の 参照記述はコンテンツの質の側面を捉えるための手 がかりとして機能する。実際に, 最初期の研究 [6] はコンテンツの質に関する問題意識から行われた。 その後, 参照記述の件数が増加すると計量書誌学分 野を中心に研究が行われている [5]. しかし，大部 分は学術文献に着目した研究であり, 参照記述を追 加する編集の分析事例は僅かである。 その理由とし て, 不完全な記述や誤りが含まれる [7] ため, 任意 のページに初めて追加されたタイミング (以下，「参 照記述の初出時点」)の特定が容易ではないことが 挙げられる. 本研究では, ある観察時点での学術文 献の参照記述を取得したうえで, 個々の初出時点を 特定する。したがって, 同時点で残存する参照記述 が対象であり，削除済の参照記述は扱わない．

次章で述べるように，先行研究は，ある観察時点 における任意のページ上での学術文献の参照状況を 把握するものがほとんどであり, 参照記述の初出時 点を特定する手法は確立されていない。これまでに 筆者ら [8] は DOI リンクが初めて追加された時点 (以下,「DOIリンクの初出時点」) を特定する手法 を提案したが, 既存の参照記述に後から DOI リン クを付加する編集が行われることが多いため, 参照 記述の初出時点を高い精度で特定可能な手法ではな い.また, Halfaker [9] は DOI や PubMed などの識 別子が任意のページに初めて追加された時点を取得 するツールを開発したが，特定精度は不明である。
参照記述の初出時点を特定する手法の構築には複 数の意義がある。たとえば，いつ頃から，ぞれだけ の参照記述が追加されてきたかに加え，その経年変 化を明らかにするためには必須である。また, 初出 時点が分かれば，その編集者を特定でき，編集者に 関しても同様の分析を実現できる，さらに，編集者 ごとの追加件数における偏りや占有状況の分析を通 じて，参照記述の持続性などを明らかにできる。こ のように，削除済の参照記述を扱わない点の制約は あるものの，これまでほとんど明らかにされていな いWikipedia 上での学術文献の参照記述の追加とい う事象を明らかにするための前提として重要である.

以上の背景から，学術文献の参照記述を追加する 編集を特定する手法を構築し, 精度の評価を行うこ とを研究目的とする。 その際, 低コストで継続的に 実行可能な方法論として, 人間による手作業の介在 を要さずに自動処理可能な手法を目指す。

本研究では, 学術文献の参照記述を「特定の学術 文献を一意に識別可能なページ本文中の記述」と定 義する。したがって，一意の文献を識別可能である 必要はあるが, 論文の引用文献リストのように, 著 者名, 文献夕イトル, 雑誌名, 出版年, 巻・号, ペー ジなどがセットで記述されていることを前提とする ものではない. 具体的には，URIや特定の識別子の みが示されている場合も, 文献を一意に識別可能で あれば対象とする。また，コンテンツの質を間接的 に担保・向上しうる情報源として参照記述を捉える 狙いから，個々の記述が本文中の脚注や出典である か否かは区別しない.

\section{2. 関連研究}

\section{1 参照記述の同定と学術文献への適用}

本研究のタスクは Wikipedia 上の参照記述の初出 時点の特定であり, 表記の摇れなどの曖昧性を伴う 文字列に対して学術文献の同定を行う必要がある。 このようなタスクはレコード同定問題と呼ばれる。

相澤ら [10] は, 「単一あるいは複数の情報源にまた がるレコード集合の中から，同一の実体を参照する ペアまたはグループを識別する問題」であるレコー ド同定問題に関して,「現実のレコード (データベー ス上のレコードや，既知の書式に従うテキストデー 夕) は表記の摇れ, 入力䛊り, 登録方針の違い等に起 因する様々なノイズを含んでおり, 単純な比較だけ 
で同一性を判定することは困難である」と述べてい る. そのうえで, 書誌同定を含むレコード同定問題 を, 重複検出, 統合, 参照先の判定, 共参照関係の 分析に分類している.これらのうち, 本研究は参照 先の判定に該当し, テキストデータの参照先をデー タベースのレコードから見つける問題である.

参照先の判定は, Web of Scienceのような学術 文献データベースでの引用索引構築に必須である. McVeigh [II] は引用索引の核となる機能として cited reference capture, cited reference linking, cited reference searching を挙げている。これらのうち, 本研究と特に関係する項目は cited reference capture と cited reference linking である. 前者は, 各 文献の引用文献リストおよび個々の引用文献を捉え る機能を指す。後述するように, 学術文献の生デー 夕からの構造化デー夕の抽出を要する場合がある. 後者は, 個々の引用文献をデータベース内のレコー ドと対応付ける処理を指す。ある文献がどの文献群 から引用されているかを把握するために必要である が, citation styleの違い, 記述の正確さ, フォー マットやバージョンの違いなどによる表記の摇れが 生じる。そのため, DOI などのグローバルな識別子 や, n-gram [112], 編集距離 [13] などを用いた照合 が行われる。さらに, 厳密な照合のために, 専門家 による目視での確認を行う場合もある [14].

Khan ら [1.5] は学術ビッグデータのサーベイにお いて, データマネジメント, データ分析と応用, 可 視化を論じている。データマネジメントに関しては, データの収集と統合, 情報抽出, 前処理, 保管と索 引付けの 4 つに整理している。これらのうち, 本研 究と特に関係する項目は情報抽出である。

情報抽出は，学術文献の生データから本文を抽 出し, 当該文献の書誌情報, 著者詳細, 引用文献, 章構成なぞの各種デー夕を取得する処理を指す。生 デー夕には PDF 形式などの非構造化デー夕が多い ため，テキスト処理や機械学習などの技術を用いて 構造化デー夕を生成するための研究開発が行われて いる.たとえば, ParsCit [I66, [7] は機械学習のひと つである条件付き確率場を用いて構造化デー夕を生 成する. 同ツールの引用文献リストの抽出および構 造化機能は, 計算機科学分野のデジタルライブラリ である CiteSeerX [18] で採用されている [119]. 同機 能のパフォーマンスは, ParsCit, FLUX-CiM [20], 条件付き確率場を用いた別のツール [2I] の比較に よる調査 [22] から, FLUX-CiM よりも優れ, 条件
付き確率場を用いた別のツールと同等である。ま た, Councill ら [I7] は複数のデータセットを用い た ParsCit の評価を行い, CiteSeerX データセット での文献タイトルの抽出の精度は $91.9 \%$, 再現率は 93.9\%，F 值は 0.93 であることなどを示している. その他，近年では Neural ParsCit [2.3] のような深層 学習を用いた手法やッールの開発が行われている.

以上に示したうち, 本研究の提案手法では識別子 と編集距離を用いる。ささらに，これまでに多くの研 究で利用され，文献夕イトルを高い精度で抽出でき ることが報告されている ParsCit を使用する.

\subsection{Wikipedia 上の参照記述の特定手法}

Wikipedia 上の参照記述の特定手法として, 先行 研究は匡1に示すように，(1) 本文テキストや外部 リンクを使用する手法，(2) ウェブ検索を使用する 手法，(3) その他に大別できる.

(1) 本文テキストや外部リンクを使用する手法 には, Nielsen [6], Teplitskiy ら [24] , 佐藤ら [25], Kikkawa ら [26]], Halfaker [9]], 吉川ら [8] が該当す る. 分析対象の言語版のデー夕を予め入手する必要 があるが，正規表現などによる柔軟な対象の指定が 可能である点が優れている. 対象は研究ごとに異な るが，いずれもページの本文テキストであるウィキ テキスト [30] または Wikipedia 以外のウェブペー ジへのハイパーリンクである外部リンクを対象に抽 出を行う。具体的には, Nielsen は出典テンプレー ト [3] のひとつである Cite journal を用いた記述を 抽出した。佐藤ら, Kikkawa ら, 吉川らは, 外部リ ンクの URI が特定のドメインに該当するものを抽 出した. Halfaker は特定の識別子の記述を抽出した.

(2) ウェブ検索を使用する手法には, Thelwall [27], Kousha \& Thelwall [28], Pooladian \& Borrego [r] が該当する。これらの研究では Bing や Google で wikipedia.org をドメイン指定したうえで, 著者名, 文献タイトル，出版年などを含むクエリを用いた検 索により参照記述を特定する. Wikipedia 全体の参 照記述を一括取得できる点が優れているが, 調査対 象群の書誌記述と, 当該文献群の件数分の検索を要 する，さらに，参照記述の著者名や文献タイトルな どが，ある程度，正確に書かれている必要がある。

(3) その他, Lin \& Fenner [29] は PLOS ALM (Article-Level Metrics) [32] を用いている. PLOS 
表 1: 先行研究における参照記述の特定手法と，本研究における提案手法の概要

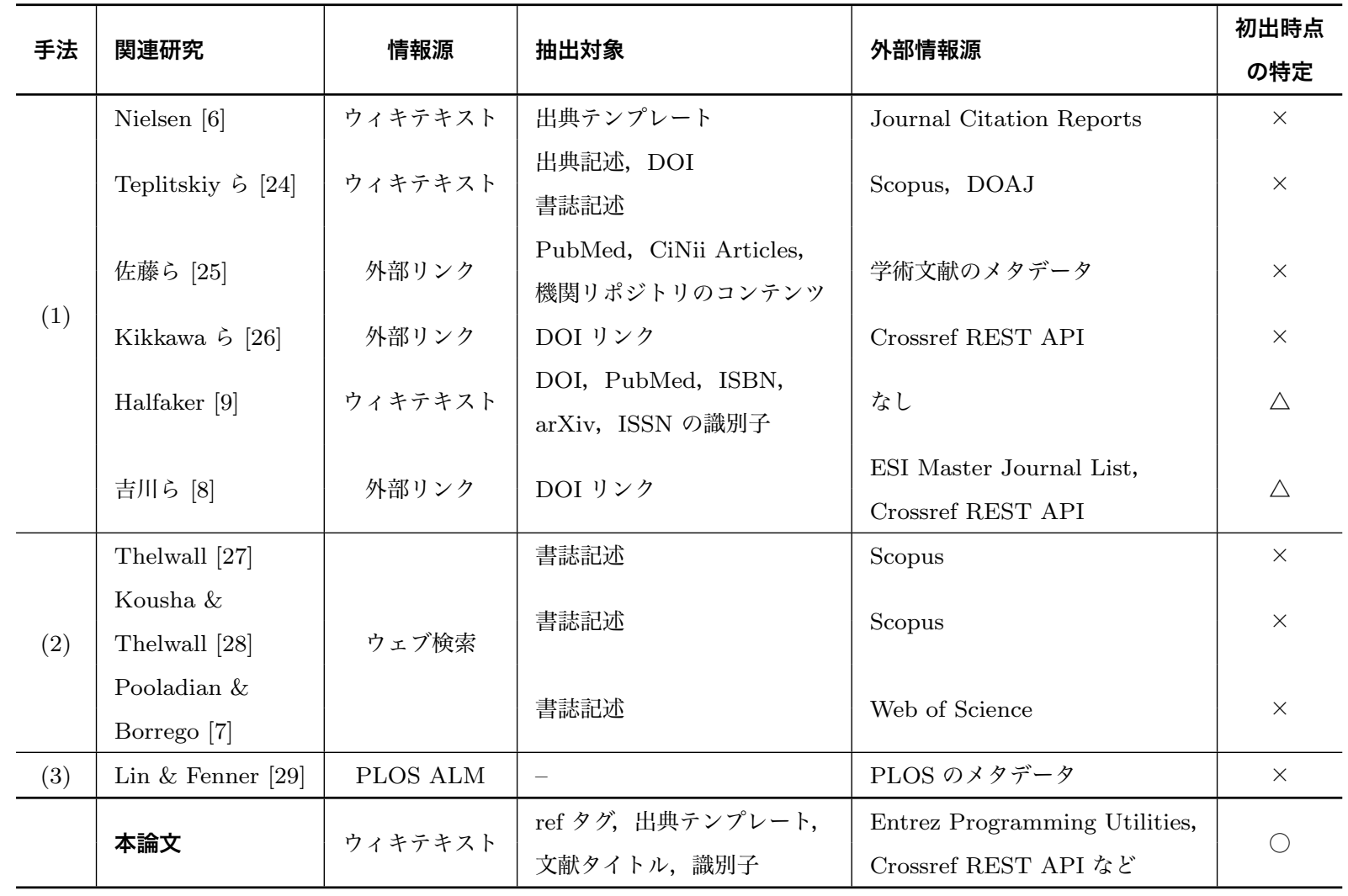

$\triangle$ は当該記述を追加した編集者の特定であり, 当該文献の参照記述自体を新規追加した編集者の特定ではない.

○は当該文献の参照記述自体を新規追加した編集者の特定である。

のコンテンツへのウェブ上での言及データを活用す る手法であるが，対象はPLOS の文献に限られる。

先行研究のうち, 参照記述の初出時点を特定可 能な手法は圊 1で初出時点の特定に「 $\triangle 」$ を付した Halfaker $[$ [ $]$ と吉川ら [8] のみである.ただし，一定 の条件を満たす記述の初出時点の特定であるため, 必ずしも参照記述自体の初出時点の特定ではない.

Halfaker は，全編集履歴を含むデータセットを用 いて，各ページの過去のすべての版のウィキテキス 卜を対象に抽出を行うことにより, PubMed, DOI, ISBN，arXiv，ISSN の識別子が，ぞの時点の編集 で追加されたかを特定した。ただし，これらの情報 を含むデータセットの構築・公開に留まっており, 詳細な分析は行われていない. 他方で, Halfaker 以 外は, 吉川ら $[8]$ を除き, 調查時点での参照状況を 取得するのみであり, 各参照記述が，ぞの編集者に よって，いつ追加されたかを特定するものではない.

吉川ら [8] は, Halfaker と同じく編集履歴を用い た方法論として，DOI リンクを追加した編集およ びその編集者を特定する手法を提案した，具体的に は, 研究分野が特定可能な学術文献の参照記述とし
ての DOI リンクを含むぺージを対象に，当該ペー ジの過去の版における外部リンクをすべて取得する ことによりDOIリンクを追加した編集を特定した。 本研究の提案手法が Halfaker [9] や吉川ら [8] と 異なる点は，特定の識別子や DOI リンクを追加し た編集ではなく，参照記述自体を新規追加した編集 を特定する点にある. 特に, 吉川ら [8] は DOI リン クのみを用いた手法であるが, 本研究では DOI 名 を含む識別子と文献タイトルを用いる点が異なる。

その他，参照記述の補完や拡充，修正を大規模か つ機械的に実行する Botである Citation bot [33,34] は, Google Books, PubMed，DOI，arXivなどを 情報源としている.

中村ら [35] は, Wikipediaのページにおいて特定 の記述がいつ追加されたかを単語レベルで追跡する 手法を提案・評価した。本研究との共通点は, 編集 履歴を用いて任意のページの版を古い順に展開し, ある条件を満たす記述を含む最も古い版を特定する 点である. 他方で, 本研究は学術文献の参照記述に 特化している点が大きく異なる. 


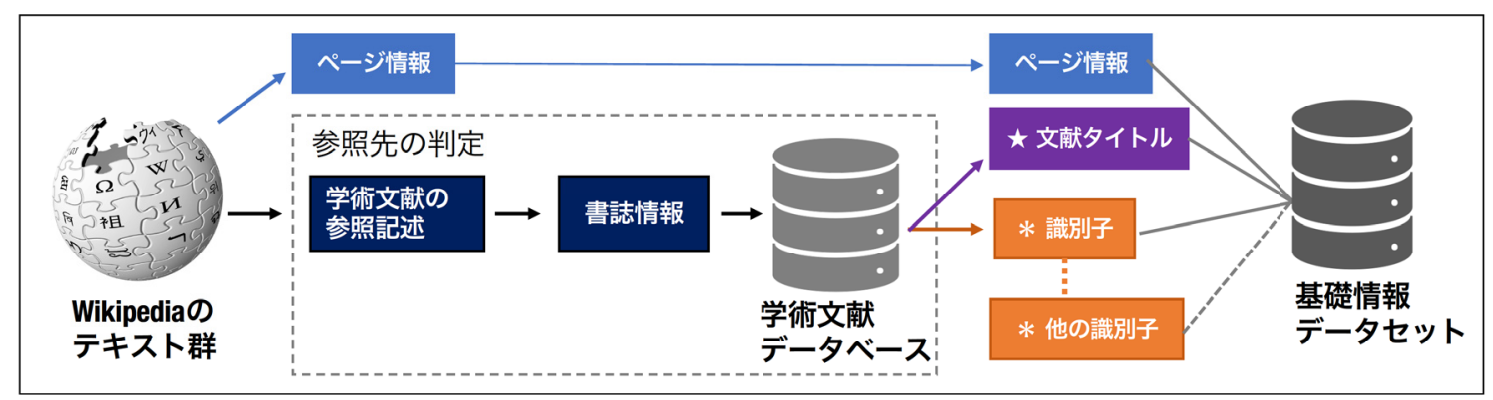

図 1: 提案手法の概要 (1) 基礎情報データセットの構築

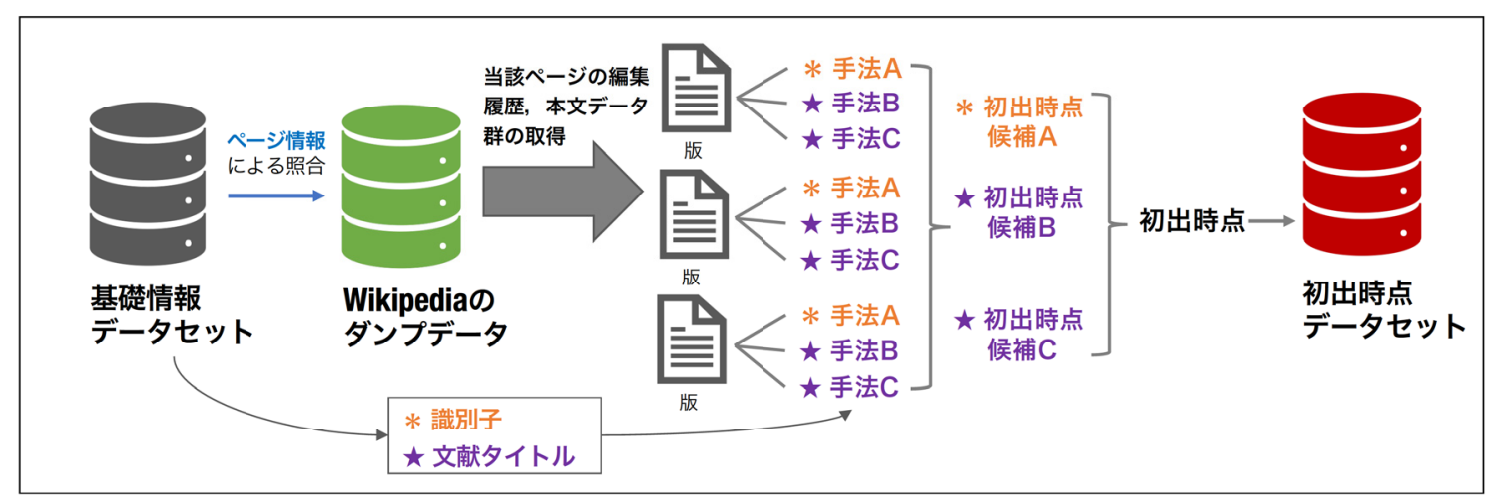

図 2: 提案手法の概要 (2) 初出時点データセットの構築

\section{3. 提案手法}

\section{1 概要}

提案手法の概要を図 1, 図 2に示す。本手法は, （1）基儊情報データセットの構築，(2) 初出時点デー タセットの構築から成る。なお，ある観察時点で残 存する参照記述の初出時点を特定するための方法論 であり，削除済の参照記述は対象としない.

まず，(1)では，任意の言語版において，どのペー ジから，どの学術文献が参照されているかを示す データセットを構筑する。この詳細は 3.2 節で示す。 次に, (2) では, 同データセットからページ情報を 抽出し, 全編集履歴抒よび各編集時点でのページ 本文を含むダンプデータとの照合によって編集履歴 と本文デー夕群を取得する。そ後, 基礎情報デー タセットから文献タイトルと識別子を抽出し，本文 データ群に対して,これらの手がかりを用いた手法 A，B，Cを適用することにより初出時点候補 A，B, $\mathrm{C}$ を取得する。ささらに, こ扎らひ候補から初出時点 を特定することで初出時点データセットを構築する. 本手法で識別子と文献タイトルを手がかりとして 用いる理由を述べる。

第一に，これまでに識別子による学術文献の参照
記述の特定手法が提案されてきた $[8,9]$. 筆者ら $[8]$ は, DOI リンクの初出時点を特定する手法を提案し た。さらに，その初出時点と直前の版を目視により 調查した結果から, 文献夕イトルや著者名, 雑誌名, 出版午などの書誌情報が記述されるよりも過去の版 に扔いて, 当該文献の DOI 名や PubMed の識別子 のみが記述されているケースの存在を報告した [8]. このような場合，識別子による特定が必須である。

第二に，2.2 節で示したウェブ検索を使用する手 法において, 検索クエリとして文献タイトルや著者 名を用いる事例 [7]や，これらに加えて出版年や雑 誌名などを用いる事例 [28]がある。ただし，著者 名や雑誌名, 出版年は, 参照記述上での要素自体の 有無に加え, 表記の摇れが生じやすく, 取得漏れに 繋がりやすいと考光る. 具体的には, 著者名は姓名 の順序やイニシャル, 雑誌名は略称表記やそのバリ エーション, 出版年は媒体が複数存在する等がその 原因となる.したがつて，このような問題が比較的 生じにくいと考えられる文献夕イトルを使用する。 


\section{2 基礎情報データセットの構築}

まず，Wikipediaのテキスト群から学術文献の参 照記述を特定し, 学術文献データベースとの照合に よる参照先の判定を行う。この処理は 2.2 節の (1) 本文テキストや外部リンクを使用する手法を応用す ることで実現できる，ただし，学術文献データベー スとの照合を伴わない手法の場合は, その処理の追 加が必要となる. 加えて, ページ情報としてページ ID やページタイトルを取得する.

次に, 学術文献デー夕ベースから識別子と文献夕 イトルを取得する，識別子が収録されていない場合 や，他の識別子を併用する場合は，別途取得する.

最後に, 取得したページ情報, 文献タイトル, 識 別子を基礎情報データセットとして格納する．以下， ある識別子の值を「ID Value」, ある文献タイトル を「Paper Title」, Paper Titleの先頭W 単語を抽 出した值を「Paper Title First $W\lrcorner$ とする.

\section{3 前処理}

本節では, 初出時点データセットの構築のための 前処理について述べる。

\subsection{1 編集履歴群の抽出}

基礎情報データセットからページ情報を抽出し， Wikipediaのダンプデータ [36] との照合を行い, 各 ページの編集履歴および本文デー夕群を取得する.

まず，ダンプデータのうち，すべてのページの全 編集履歴と各編集時点でのページ本文を格納した デー夕群を入手する。個々の編集は版 (revision) と して管理されており，ページ本文以外に，版の ID， 編集日時, 編集コメント, 編集者の情報などが含ま れる。また，ここでのページ本文はウィキテキスト で記述されたものを指す，以下，ある版のページ本 文を「Page Text」とする.

次に, ページ ID またはページタイトルでの照合 により，各ページの全編集履歴と全 Page Text を取 得し，ページごとに編集日時の古い順にソートする.

\subsection{2 参照記述における文献タイトルの抽出}

3.4 節で後述する手法 $\mathrm{C}$ では，軽微な表記の摇れ や入力誤り等が含まれるケースでの初出時点の特定
のために Page Text から参照記述における文献夕イ トルを抽出し, Paper Title との文字列間の類似度 による照合を行う。

まず，それぞれの版の Page Textから参照記述を 抽出する。具体的には，<ref>タグで囲まれた脚注 と，名称が Cit で始まるテンプレートを用いた記述 を抽出する。後者は, Citation や Cite journal など の出典テンプレートを用いた記述の抽出を指す.

次に, 参照記述における文献夕イトルを特定する. 具体例を亚 2に示す。表 2 の例 1 は Cite journal を 用いて構造化されており，この場合は titleの值を使 用する. 他方で, 例 2 は< ref $>$ タグのみを用いた記 述であり，構造化されていないため，これらの夕グ 情報を除去したうえで ParsCit [16,[7] での解析を行 い, title と判定された筒所を使用する。例 1 は「Dynamic capabilities and strategic management $\lrcorner$, 例 2 は「Correlates of (中略) second year.」が参照記述 における文献タイトル (以下, 「Ref Title」) となる。

\subsection{3 テキストの正規化処理}

テキストの正規化処理として次の 3 つを設定する.

処理 1 文字列の小文字化とアンエスケープ処理を行う

処理 2 処理 1 に加え, 次の記号および文字を削除する: [ ], '? 改行, タブ記号

処理 3 処理 1 , 処理 2 に加え, 空白文字を削除する

これらの処理は, 文字列照合時のノイズを除去す るために行う。なお，一部にはウィキテキストの記 法として特別な意味を有する記号が含まれる。たと えば，処理 2 での角括弧は文献タイトル内の単語に 対応する Wikipedia のページへのリンクを張るため に使用される. シングルクオートは文献タイトル内 の単語を斜体や太字で表記するために使用される。

正規化処理適用後のデータの名称と説明を表 $3 に$ 示す。たとえば，ある識別子の值 ID Value に処理 1 を適用した值を ID Value1 とする。 また，ある文献 タイトル Paper Title に対し, 処理 1 を適用した值を Paper Title1，処理 2 を適用した值を Paper Title2, 処理 3 を適用した值を Paper Title3 とする。なお, 名称の末尾の数字は，適用する処理に対応する. 
表 2: 参照記述からの文献夕イトルの抽出例

\begin{tabular}{|c|c|}
\hline 項目 & 参照記述 \\
\hline \multirow{3}{*}{ 例 1} & $\langle$ ref $>\{\{$ cite journal $\mid$ last $1=$ Teece $\mid$ first $1=D . \mid$ last $2=$ Pisano $\mid$ first $2=G . \mid$ last $3=$ Shuen $\mid$ first $3=A . \mid$ \\
\hline & title= Dynamic capabilities and strategic management $\mid$ \\
\hline & journal=Strategic Management Journal $\mid$ date=1997 $\mid$ volume=18|pages=509-534\} $\}</$ ref $\rangle$ \\
\hline \multirow[t]{2}{*}{ 例 2} & $\begin{array}{l}<\text { ref }>\text { Frodi, A., Bridges, L., \& Grolnick, W. S. (1985). Correlates of mastery-related } \\
\text { behaviour: A short term longitudinal study of infant in their second year. }\end{array}$ \\
\hline & Child Development, 56, 1291-1298.</ref > \\
\hline
\end{tabular}

※下線部分は文献タイトルを示す。

表 3: 正規化処理適用後のデー夕の名称と説明

\begin{tabular}{|c|c|}
\hline 名称 & 説明 \\
\hline ID Value1 & ID Value に処理 1 を適用した值 \\
\hline Paper Title1 & Paper Title に処理 1 を適用した值 \\
\hline Paper Title2 & Paper Title に処理 2 を適用した值 \\
\hline Paper Title3 & Paper Title に処理 3 を適用した值 \\
\hline Paper Title First $_{W} 1$ & $\begin{array}{l}\text { Paper Title First } W \text { に処理 } 1 \text { を } \\
\text { 適用した值 }\end{array}$ \\
\hline Paper Title First $_{W} 2$ & $\begin{array}{l}\text { Paper Title First } W \text { に処理 } 2 \text { を } \\
\text { 適用した值 }\end{array}$ \\
\hline Paper Title First $_{W} 3$ & $\begin{array}{l}\text { Paper Title First } W \text { に処理 } 3 \text { を } \\
\text { 適用した值 }\end{array}$ \\
\hline Ref Title3 & Ref Title に処理 3 を適用した值 \\
\hline Page Text1 & Page Text に処理 1 を適用した值 \\
\hline Page Text2 & Page Text に処理 2 を適用した值 \\
\hline Page Text3 & Page Text に処理 3 を適用した值 \\
\hline
\end{tabular}

\section{4 初出時点データセットの構築}

\subsection{1初出時点候補の取得}

正規化処理適用後, 以下に示す手法 $\mathrm{A}, \mathrm{B}, \mathrm{C}$ に より, 任意のページにおいて, 任意の参照記述が初 めて追加された版の候補 (以下, 「初出時点候補」と 呼ぶ) として, 初出時点候補 $\mathrm{A}, \mathrm{B}, \mathrm{C}$ を取得する.

\section{（1）手法 A}

手法 A では識別子による照合を行う。まず，基礎 情報データセットからページ情報と当該ページ上の 各ID Valueを取得する。また, 編集履歴および本 文デー夕群から各ページのすべての版の Page Text を取得する。そのうえで，正規化処理を適用する。 次に, Page Text1 がID Value1 を含む版のうち, 編集日時が最古のものを初出時点候補 A とする. 同
一文献に複数の ID Value1 がある場合は，それらの いずれかを含む版のうち, 編集日時が最古のものを 選択する。

\section{（2）手法 B}

手法 B では文献夕イトルの全体または先頭 $\mathrm{W}$ 単 語による照合を行う。まず, 基礎情報データセットか らページ情報と Paper Titleを抽出し, さらに Paper Title First ${ }_{W}$ を得る。 また, 各ページの編集履歴お よび本文デー夕群からすべての版の Page Text を取 得する。そのうえで, 正規化処理を適用する.

次に, 以下の条件 1 から条件 6 までのいずれかを 満たす版のうち, 編集日時が最古のものを初出時点 候補 B とする.

条件 1 Page Text1 が Paper Title1 を含む

条件 2 Page Text2 が Paper Title2 を含む

条件 3 Page Text3 が Paper Title3 を含む

条件 4 Page Text1 が Paper Title First ${ }_{W} 1$ を含む

条件 5 Page Text2 が Paper Title First ${ }_{W} 2$ を含む

条件 6 Page Text3 が Paper Title First ${ }_{W} 3$ を含む

文献タイトル全体だけでなく, 先頭 $\mathrm{W}$ 単語での 照合を行う理由は, 前者ではヒットしないが後者で はヒットするケースが考えられるためである。

\section{(3) 手法 C}

手法 Cでは，軽微な表記の摇れや入力䛊りなどを 含む場合の初出時点候補の検出を意図した処理とし て，文献タイトル間の類似度を用いた照合を行う。 手法 B との相違点は, 第一に, 手法 B が文献夕イ トルの全体または一部での完全一致による照合であ るのに対し, 文字列間の類似度を用いる点である。 
第二に，手法 B はページ本文全体での照合を行う のに対し，参照記述における文献夕イトルを抽出し たうえで照合を行う点である。

まず，基礎情報データセットから，ページ情報と， 当該ページの各 Paper Titleを取得する. また, 各 ページの編集履歴および本文デー夕群から，すべて の版の Page Textを取得する。ささらに, Page Text に含まれる Ref Titleをすべて抽出する。そのうえ で，正規化処理を適用する.

次に, Paper Title3 と Ref Title3 のペアをすべて 取得し，それぞれの編集距離を算出する。編集距離

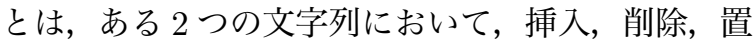
換の操作により一方を他方へと変換するために必要 な操作回数の最小值 [37] である. 本手法ではレーベ ンシュタイン距離 [38] を使用する。ただし，文字列 長を考慮した類似度ではないため，1 文字あたりの 平均的な操作回数として，レーベンシュタイン距離 をいずれか長いほうの文字列長で除算した值 (以下, 「類似度スコア」) を用いる。類似度スコアは 0 から 1 までの值を取り，值が小さいほど類似度が高い.

レーベンシュタイン距離と類似度スコアの算出 例を示す。圊 2 の例 2 は, Self-determination theory の過去の版 [39] の参照記述であり, Ref Title は "Correlates of mastery-related behaviour: A short term longitudinal study of infant in their second year.”である。同文献は JSTOR で公開されてお り [40], JSTOR 上での文献タイトルを Paper Title とすると "Correlates of Mastery-Related Behavior: A Short-Term Longitudinal Study of Infants in Their Second Year"である. このとき, Ref Title3 と Paper Title3 では「behaviour」と「behavior」, 「infant」と「infants」の 2 箇所が異なり, レーベン シュタイン距離は 2 である. 文字列長は両者ともに 87 であり, 類似度スコアは $2 / 87=0.023$ となる。

最後に，類似度スコアがある閾值以下である版の うち, 編集日時が最古のものを初出時点候補 $\mathrm{C}$ と する。なお，この閾值には任意の值を設定できる。

\subsection{2 初出時点の特定}

本手法では，任意のページでの任意の参照記述の 初出時点として, 初出時点候補 $\mathrm{A}, \mathrm{B}, \mathrm{C}$ のうち, 編集日時が最古のものを使用する.

\section{4. 評価実験}

\section{1 実験条件}

\section{（1）文献タイトルにおける先頭 W 単語}

手法 B での文献夕イトルの先頭 $\mathrm{W}$ 単語として, $\mathrm{W}$ に 1 から 10 までの值を指定し, それぞれの条件 での精度を調査する。そのうえで，精度を踏まえて 先頭単語数を設定する。 さらに, 文献夕イトル全体 のみでなく, 先頭 $\mathrm{W}$ 単語での照合を行うことによ る初出時点の特定精度への影響を明らかにする.

\section{(2) 文献タイトル間の類似度スコアの閾値}

手法 Cでの文献夕イトル間の類似度スコアの閾值 として 0 から 1 までの值を 0.05 刻みで指定し，それ ぞれの条件での精度を調べたうえで閾值を設定する。

\section{2 基礎情報データセットの構築}

基礎情報データセットとして, DOI リンクの初出 時点データセットに一部のデータを追加したものを 使用する。 その理由として，次の 3 点が挙げられる.

1 点目には，最大規模の言語版である英語版を対 象とした大規模なデータセットであることが挙げら れる。このことから, 提案手法を適用し, 精度の評 価を行う対象として適切と考える。加えて，もし， 英語版に適用可能であることが確認できれば，他の 言語版にも適用可能な手法として期待できる.

2 点目には, 研究分野が特定可能な学術文献に対 象を限定したデータセットであるため，分野ごとの 精度の評価や比較が可能であることが挙げられる。

3 点目には, DOI 名と紐付いているため, 出版者 や学協会などが登録した書誌情報を機械的に入手可 能であることが挙げられる。これにより書誌情報を 一元的に取得でき，より正確な書誌情報に基づき， 後述の初出時点候補の正誤判定を行うことができる.

以下，(1) 学術文献の参照記述の抽出と参照先の 判定，(2) 文献夕イトルの取得と識別子の追加取得 について述べる。

\section{（1）学術文献の参照記述の抽出と参照先の判定}

学術文献の参照記述の抽出と参照先の判定として, DOI リンクの初出時点データセットの構築手法を 示す。同データセットは 2017 年 3 月 1 日時点の英 語版において研究分野が特定可能な学術文献の参照 
記述を抽出し, 参照先の判定を行ったものである. DOI 名の延べ数は 926,803 件, 異なり数は 611,524 件である。ページの異なり数は 181,162 件である.

学術文献の参照記述は, DOI リンクの抽出によ り取得した。学術文献データベースとの照合では Crossref REST API [4I] により取得した Crossref のメタデー夕を用いた。 そのうえで, 百科事典ペー ジを意味する標準名前空間上の DOI リンク，かつ， Crossref DOI に対象を限定した。 また, Crossref の メタデータでのコンテンツ種別が学術文献に該当し, かつ, InCites Essential Science Indicators [42] の 2017 年 8 月版の Master Journal List [4.3] により分 野特定可能な雑誌の掲載文献に対象を限定し, ISSN を用いた照合により 22 分野 (以下, 「ESI 分類」) と の紐付けを行った. ESI 分類の一覧を匡 4 に示す. 日本語表記は小野寺 [44] を参照した。略記として, 日本語表記の先頭 2 文字を用いる.

表 4: ESI 分類の一覧

\begin{tabular}{|c|c|c|}
\hline 英語表記 & 日本語表記 & 略記 \\
\hline Agricultural Sciences & 農学 & 農学 \\
\hline Biology \& Biochemistry & 生物学・生化学 & 生物 \\
\hline Chemistry & 化学 & 化学 \\
\hline Clinical Medicine & 臨床医学 & 臨床 \\
\hline Computer Science & 計算科学 & 計算 \\
\hline Economics \& Business & 経済学・ビジネス & 経済 \\
\hline Engineering & 工学 & 工学 \\
\hline Environment/Ecology & 環境・エコロジー & 環境 \\
\hline Geosciences & 地球科学 & 地球 \\
\hline Immunology & 免疫学 & 免疫 \\
\hline Materials Science & 材料科学 & 材料 \\
\hline Mathematics & 数学 & 数学 \\
\hline Microbiology & 微生物学 & 微生 \\
\hline $\begin{array}{l}\text { Molecular Biology } \\
\& \text { Genetics }\end{array}$ & 分子生物学 · 遺伝学 & 分子 \\
\hline Multidisciplinary & 多領域科学 & 多領 \\
\hline Neuroscience \& Behavior & 神経科学・行動科学 & 神経 \\
\hline $\begin{array}{l}\text { Pharmacology } \\
\text { \& Toxicology }\end{array}$ & 薬学・毒物学 & 薬学 \\
\hline Physics & 物理学 & 物理 \\
\hline Plant \& Animal Science & 動植物学 & 動植 \\
\hline Psychiatry/Psychology & 精神学・ 心理学 & 精神 \\
\hline Social Sciences, General & 社会科学一般 & 社会 \\
\hline Space Science & 天体科学 & 天体 \\
\hline
\end{tabular}

\section{(2) 文献タイトルの取得と識別子の追加取得}

まず，文献夕イトルの取得では，Crossref のメ夕 データの「title」を抽出した．空值の場合はDOIリ ンクを通じて文献にアクセスし, 手作業で取得した。 次に, 識別子を用いてより多くの初出時点候補 を得るために, DOI Suffix, PMID, PMCID, Bibcode, alternative id の追加取得を行った. 以下, 各 識別子の概要と取得方法について述べる.

DOI Suffix はDOI 名の構成要素であり, DOI 名 の最初のスラッシュより後ろの部分を指す。一部の 出版者やプラットフォームでは自身の識別子の全体 または一部が DOI Suffix と同一の場合があるため, DOI 名に加えて DOI Suffix での照合を行う.

PMID は, 生物医学および生命科学分野での世界 最大規模の学術文献データベースである PubMed の 識別子を指す. PMCID は, 同分野の論文アーカイブ である PMC の識別子を指す，值の形式は, PMID は数值列, PMCID は数值列の前に PMC が付く. 出典テンプレートでは「 $\ulcorner$ mid=数值列」, $\ulcorner\mathrm{pmc}=$ 数 值列」のように記述する場合があるため, いずれも 数值列のみを用いる. 以下, PMID と PMCID を総 称して「PubMed」と表記する。これらの取得には Entrez Programming Utilities [45] を用いた.

Bibcode は, 天体物理学分野のデータベースであ る The SAO/NASA Astrophysics Data System の 識別子であり, Abstract Links [46] により取得した。 alternative id は, Crossrefのメタデータにおける 「alternative-id」の值であり, 書誌情報を登録した Crossref のメンバーによって提供された, 当該コン テンツに対するその他の識別子 [47] を指す。なお， 識別子以外の記述の誤検出を回避するため, 文字列 長が 10 文字未満のものは予め除外した.

(1), (2) の処理により, ページ情報, 文献夕イト ル, 識別子を取得し, 基礎情報データセットを構築 した。後述の編集履歴群の抽出で 12 件のページが 照合できなかったため, これらのページと当該ペー ジ上の 193 件の参照記述は除外した。したがって, 基礎情報データセットにおける DOI 名の延べ数は 926,610 件, 異なり数は 611,400 件である. ページ の異なり数は 181,150 件である. 611,400 件の DOI 名のうち, PubMed との対応関係を有するものは 348,563 件 $(57.0 \%)$ である. また, alternative id は 169,613 件 (27.7\%), Bibcodeは 104,903 件 $(17.2 \%)$ が DOI 名との対応関係を有する. 


\section{3 前処理}

\subsection{1 編集履歴群の抽出}

2017 年 3 月 1 日時点での英語版のダンプデー 夕 [48] を取得し, 基礎情報データセットとの照合に より編集履歴と各版のページ本文を抽出した。この 際, ページ ID が照合できなかった 12 件のページ と，当該ページ上の 193 件の参照記述は除外した。 以上の処理により，181,150 件のページにおける 49,325,731 件の編集履歴および各版のページ本文を 取得した。ページごとの編集履歴の件数における最 大值は 36,934 , 最小值は 1 , 中央值は 213.5 である.

\subsection{2 参照記述における文献タイトルの抽出}

各版のページ本文に 3.3 .2 項の処理を適用した。 具体的には，49,325,731 件のページ本文に含まれる 1,377,585,921 件の < ref>タグで囲まれた記述また は名称が Cit で始まるテンプレートを用いた記述を 取得したうえで，それぞれの文献夕イトルを抽出し た。 なお，この件数は，同一ページ内に同じ記述が 存在する場合の重複分を除外した值である.

\subsection{3 テキストの正規化処理}

テキストの正規化処理として，4.2節，4.3節で の取得データに 3.3 .3 項の処理を適用した。

\section{4 サンプルデータの取得と正誤判定}

\subsection{1 無作為抽出によるサンプルデータの取得}

まず，各分野から 50 件ずつのサンプルを無作為 抽出した. サンプル数の設定理由は, 作業コストの 制約によるものである。具体的には, 手法 A では 1 通り, 手法 $\mathrm{B}$ では先頭単語数 $\mathrm{W}$ の值による 10 通 り, 手法 Cでは類似度の閾値による 21 通りが存在 するため, 最大で 35,200 件 (22 分野 $* 50$ 件 $* 32$ 通 り)に対して後述の初出時点候補の正誤判定を筆頭 著者がすべて目視で行う必要があるためである.

次に, 各手法での初出時点候補 $\mathrm{A}, \mathrm{B}, \mathrm{C}$ と, それ ぞれの初出時点候補に対する直前の版を取得した。

\subsection{2 初出時点候補の正誤判定}

初出時点候補とその直前の版との差分 [4.9] を目 視で確認し, 初出時点候補が実際の初出時点である か否かの正誤判定を行った. 初出時点候補での参照 記述が当該文献を一意に識別可能であり, かつ, 直 前の版に同様の記述が存在しない場合は正解とし, それ以外はすべて不正解とした。

初出時点候補に関しては，DOI名や文献タイトル のほか, Crossref のメタデー夕における著者名, 雑 誌名, 出版年, 巻・号, ページなどの情報を踏まえ, 検出䇢所が当該文献を指す記述か否かを個別に判定 した．別の文献を指す可能性がある記述の場合は, ウェブ検索による確認を行ったうえで判定した。

直前の版に関しては, 目視で何らかの参照記述に 該当する䇢所を探したうえで, 識別子や文献夕イト ルのみでなく, 著者名, 雑誌名, 出版年, 巻・号, ページなぞの記述を踏まえ, 当該文献を指す記述か 否かを個別に判定した. URIのみが示されている場 合は実際にアクセスして判定を行った。リンク切れ によりコンテンツが確認できない場合は，その URI が当該文献を指す可能性があることから, 初出時点 候補に対する判定は不正解とした。

初出時点候補の正誤判定の例を図3に示す。なお, ここでの手法 $\mathrm{B}$ の先頭単語数は 5 , 手法 $\mathrm{C}$ での類 似度スコアの閾值は 0.20 である.ケース番号の真 下は判定結果, 真横は初出時点の特定対象のページ 名, DOI 名, 文献夕イトル, 直前の版との差分の URIである. その下が直前の版との差分の抜粋であ り, 右側の星印を付したものが初出時点候補, 左側 がその直前の版を示す. Revision as of の行は編集 日時であり, その下は編集者名, 編集コメントであ る.さらに下の枠内はページ本文である. ページ本 文の着色部分は, 初出時点候補の版で追加された内 容を示す. 初出時点候補のページ本文中の太字は, 当該文献の参照記述として検出された箇所を示す. 直前の版での太字は, 目視により当該文献の参照記 述と判定した箇所を示す.

図3のケース 1 は手法 $\mathrm{B} ， \mathrm{C}$ での取得結果であり, 正解と判定した。初出時点候補は 2011 年 1 月 8 日 18 時 24 分の版であり, 当該文献の参照記述が新規 追加されている，ケース 2 は手法 A での取得結果 であり，2014 年 1 月 25 日 18 時 58 分の版であるが, 既出の参照記述に DOI 名を追加しているため不正 解と判定した. ケース 1 とケース 2 の対象ページお 


\begin{tabular}{|c|c|c|c|}
\hline $\begin{array}{l}\text { ケース } 1 \\
\text { 正解 }\end{array}$ & $\begin{array}{l}\text { ページ名 } \\
\text { DOI名 } \\
\text { 文献タイトル } \\
\text { 直前の版との差分 }\end{array}$ & \multicolumn{2}{|c|}{$\begin{array}{l}\text { Plains zebra } \\
\text { 10.1016/j.biocon.2004.08.007 } \\
\text { Competition and compensation among cattle, zebras, and elephants } \\
\text { in a semi-arid savanna in Laikipia, Kenya } \\
\text { https://en.wikipedia.org/w/index.php?diff=406717907\&oldid=prev }\end{array}$} \\
\hline \multicolumn{3}{|c|}{$\begin{array}{l}\text { Revision as of 18:16, } 8 \text { January } 2011 \\
\text { Mukogodo } \\
(\rightarrow \text { Interactions with other grazers })\end{array}$} & $\begin{array}{c}\star \text { Revision as of 18:24, } 8 \text { January } 2011 \\
\text { Mukogodo } \\
(\rightarrow \text { Conservation })\end{array}$ \\
\hline \multicolumn{3}{|c|}{$\begin{array}{l}\text { Some local populations, though, have faced great declines } \\
\text { and (省略) They also compete with livestock for food. } \\
\text { Poaching is (省略) }\end{array}$} & $\begin{array}{l}\text { Some local populations, though, have faced great declines } \\
\text { and (省略) They also compete with livestock for food } \\
\text { <ref name }=\text { comp }>\{\text { CCite journal I last }=\text { Young I first }= \\
\text { T.P. I coauthors }=\text { T.M. Palmer \& M.E }>\text { Gadd I title }= \\
\text { + Competition and compensation among cattle, zebras, and } \\
\text { elephants in a semi-arid savanna in Laikipia, Kenya I } \\
\text { journal }=\text { Biological conservation I volume }=121 \text { I pages } \\
=351-359 \text { I year }=2005\}\}</ \text { ref }>\text {, and are sometimes } \\
\text { culled. Poaching is (省略) }\end{array}$ \\
\hline $\begin{array}{l}\text { ケース2 } \\
\text { 不正解 }\end{array}$ & $\begin{array}{l}\text { ページ名 } \\
\text { DOI名 } \\
\text { 文献タイトル } \\
\text { 直前の版との差分 }\end{array}$ & \multicolumn{2}{|c|}{$\begin{array}{l}\text { Plains zebra } \\
10.1016 / j . b i o c o n .2004 .08 .007 \\
\text { Competition and compensation among cattle, zebras, and elephants } \\
\text { in a semi-arid savanna in Laikipia, Kenya } \\
\text { https://en.wikipedia.org/w/index.php?diff=592361091\&oldid=prev }\end{array}$} \\
\hline \multicolumn{3}{|c|}{$\begin{array}{l}\text { Revision as of 00:51, } \mathbf{1 7} \text { January } 2014 \\
\quad \text { ClueBot NG } \\
\text { verting possible vandalism by 67.238.196.236 to version } \\
\text { stlettersandnumbers. False positive? Report it. Thanks, } \\
\text { ClueBot NG. (1657239) (Bot)) }\end{array}$} & $\begin{array}{c}\star \text { Revision as of 18:58, } 25 \text { January } 2014 \\
\text { Rjwilmsi } \\
\text { m (Journal cites, added } 2 \text { DOls using AWB (9887)) }\end{array}$ \\
\hline \multicolumn{3}{|c|}{$\begin{array}{l}\text { Some local populations, (省略). They also compete with } \\
\text { livestock for food, } \\
\text { <ref name =comp }>\{\text { CCite journal I last = Young I first = T. } \\
\text { P. I coauthors = T. M. Palmer \& M. E. Gadd I title = } \\
\text { Competition and compensation among cattle, zebras, and } \\
\text { elephants in a semi-arid savanna in Laikipia, Kenya I } \\
\text { journal = Biological Conservation I volume = 121 I pages = } \\
\text { 351-359 | year = 2005\}\}</ref> }\end{array}$} & $\begin{array}{l}\text { Some local populations, (省略). They also compete with } \\
\text { livestock for food, } \\
\text { <ref name=comp> }>\{\text { Cite journal I last = Young I first = T. } \\
\text { P. I coauthors = T. M. Palmer \& M. E. Gadd I title = } \\
\text { + Competition and compensation among cattle, zebras, and } \\
\text { elephants in a semi-arid savanna in Laikipia, Kenya I } \\
\text { journal = Biological Conservation I volume = 121 I pages = } \\
351-359 \text { | year }=2005 \text { I } \\
\text { doi=10.1016/j.biocon.2004.08.007\} }\}</ \text { ref> }\end{array}$ \\
\hline $\begin{array}{l}\text { ケース3 } \\
\text { 不正解 }\end{array}$ & $\begin{array}{l}\text { ページ名 } \\
\text { DOI名 } \\
\text { 文献タイトル } \\
\text { 直前の版との差分 }\end{array}$ & \multicolumn{2}{|c|}{$\begin{array}{l}\text { List of off-season Atlantic hurricanes } \\
\text { 10.1175/1520-0493(1975)103<0285:ahso>2.0.c0;2 } \\
\text { Atlantic Hurricane Season of } 1974 \\
\text { https://en.wikipedia.org/w/index.php?diff=208317414\&oldid=prev }\end{array}$} \\
\hline \multirow{2}{*}{\multicolumn{3}{|c|}{$\begin{array}{c}\text { Revision as of 13:16, } 26 \text { April } 2008 \\
\text { Hello32020 } \\
(\rightarrow \text { December: add zeta })\end{array}$}} & $\begin{array}{c}\star \text { Revision as of 13:39, } 26 \text { April } 2008 \\
\text { Hello32020 } \\
\text { (add arlene) }\end{array}$ \\
\hline & & & $\begin{array}{l}\text { [[May 6]]-[[May 9]], [1981]]] - A system moved across from } \\
\text { (省略). Arlene dissipated east of the [[Bahamas]] and } \\
\text { <erged with a cloud mass. } \\
\text { <ref name="arlenemwr">\{[cite web I format=PDF I } \\
\text { author=Miles B. Lawrence; Joseph M. Pelissier I } \\
\text { title=Atlantic Hurricane Season of 1981 I } \\
\text { publisher=[[Monthly Weather Review]] I } \\
\text { accessdate=2008-04-26 I } \\
\text { url=http:///www.aoml.noaa.gov/general/lib/lib1/nhclib/mw } \\
\text { reviews/1981.pdf\}\}</ref> }\end{array}$ \\
\hline \multirow[t]{3}{*}{$\begin{array}{l}\text { ケース4 } \\
\text { 不正解 }\end{array}$} & $\begin{array}{l}\text { ページ名 } \\
\text { DOI名 } \\
\text { 文献タイトル } \\
\text { 直前の版との差分 }\end{array}$ & \multicolumn{2}{|c|}{$\begin{array}{l}\text { Apache Point Observatory Lunar Laser-ranging Operation } \\
\text { 10.1086/526428 } \\
\text { The Apache Point Observatory Lunar Laser-ranging Operation: } \\
\text { Instrument Description and First Detections } \\
\text { https://en.wikipedia.org/w/index.php?diff=6945668\&oldid=prev }\end{array}$} \\
\hline & & & $\begin{array}{c}\star \text { Revision as of 19:58, } 21 \text { July } 2004 \\
\text { Finn-Zoltan }\end{array}$ \\
\hline & & & $\begin{array}{l}\text { The "'Apache Point Observatory Lunar Laser-ranging } \\
\text { Operation'”, or APOLLO, is a project at the } \\
\text { [[Apache Point Observatory]] (省略) }\end{array}$ \\
\hline
\end{tabular}


よび文献は同一であり, 最も編集日時が古いケース 1 の初出時点候補が初出時点として選択される.

ケース 3 は手法 C での取得結果であり，2008 年 4 月 26 日 13 時 39 分の版である. 太字で示した要 素は直前の版には存在しないが，文献タイトルは $\ulcorner$ Atlantic Hurricane Season of 1981」であり, 特定 対象の文献夕イトルの末尾は 1974 であるため, 別の 文献 [50] の参照記述の誤検出による不正解とした. ケース 4 は手法 B での取得結果であり，2004 年 7 月 21 日 19 時 58 分の版である. 当該ページの初 版のため, 直前の版は存在しない.太字の箇所は参 照記述ではないため, 誤検出による不正解とした

\section{5 サンプルデータを用いた精度の評佃}

本節では，サンプルデータを用いた精度の評価に ついて述べる. 精度は, 正解と判定された初出時上 候補 (以下，正解数) の割合とする。本節ではサ: プル全体の精度を示し，母数はすべて 1,100 である

\subsection{1 手法単体での精度の評価}

\section{（1）文献タイトルの先頭 $\mathrm{W}$ 単語と精度の関係}

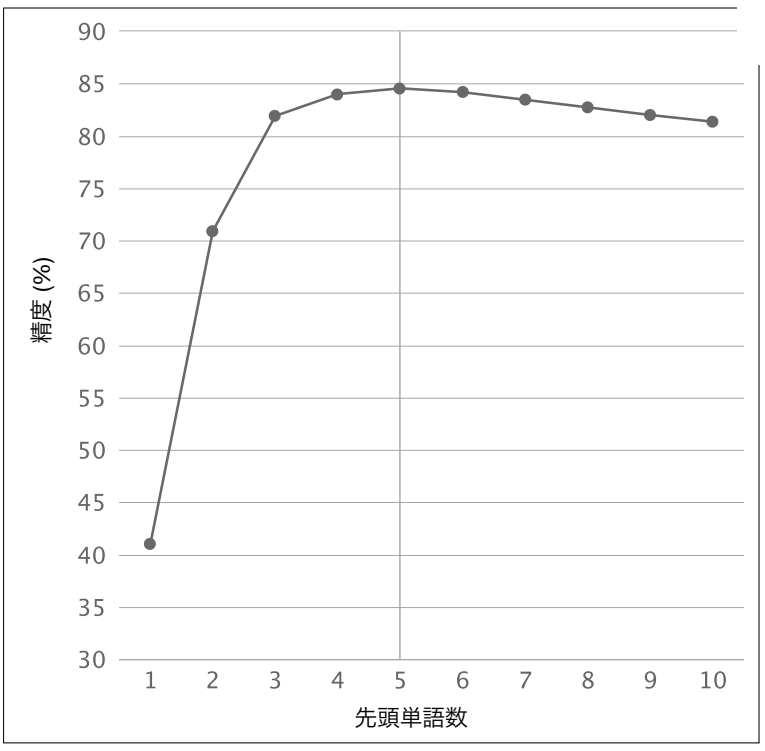

図 4: 先頭単語数ごとの精度

手法 B での先頭単語数ごとの精度を図4に示す。 精度は先頭単語数が 5 で最大值 $(84.6 \%)$ を取り，6 以降では単語数が増えるにつれて低下する。
この結果から, 先頭単語数が 1 や 2 のときは当該 文献夕イトル以外を誤検出するケースが多く, 3 以 上では誤検出が減少する. 先頭単語数が 5 での精度 が最も高いため, 文献タイトル全体の照合では検出 できないが，先頭 5 単語の照合では検出できるケー スが多い. 他方で, 先頭単語数が 6 以上になると文 献タイトル全体での照合との差異が小さくなるため, 精度向上への寄与が小さくなると解釈できる.

以上の結果から, 先頭単語数の設定は 5 とする.

\section{（2）類似度スコアの閾値と精度の関係}

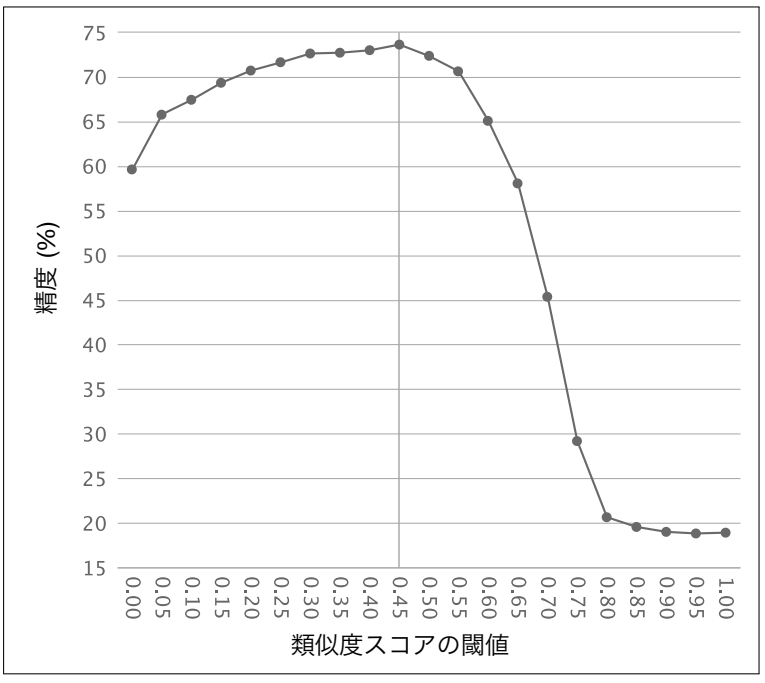

図 5: 類似度スコアの閾值ごとの精度

手法 C における類似度スコアの閾值ごとの精度 を図5に示す。まず，間值が 0 ，すなわち，文献夕 イトルが完全に一致する場合のみを検出したときは 59.6\%である。 0.05 から 0.60 までの範囲では，いず れも閾值が 0 のときよりも高いため, 軽微な表記の 摇れや入力誤り等を含むケースを検出することで精 度の向上に寄与している. 他方で, 0.65 から 1 まで の範囲では, 誤検出が増加するために閾值が 0 のと きよりも精度が低下すると解釈できる。

次に，精度は閾值が 0.45 のときに最大值 $(73.6 \%)$ を取るため, 手法 $\mathrm{C}$ 単体での閾值は 0.45 が最適と 考えられる。ただし，提案手法では手法 $\mathrm{A}, \mathrm{B}, \mathrm{C}$ を組み合わせて初出時点を特定するため, 手法 $\mathrm{C}$ 単 体と提案手法では, 精度が高くなる類似度スコアの 閾值が異なる可能性がある。この点を踏まえ, 複数 の手法を組み合わせた場合の精度を次項に示す。 


\subsection{2 複数の手法を組み合わせた場合の精度}

提案手法での精度が高くなるときの手法 $\mathrm{C}$ の類 似度スコアの閾值の条件を圊 5に示す。前項の結果 を踏まえ，手法 B の先頭単語数は 5 とした. 表 5 よ り，提案手法の精度は閾值が 0.20 のときに $93.3 \%$ で最大值を取ることから，閾值を 0.20 に設定する。 表 5: 提案手法において精度が高くなる閾値の条件

\begin{tabular}{ccrc}
\hline 順位 & 閾値 & 正解数 & 精度 \\
\hline 1 & 0.20 & 1,026 & 93.3 \\
2 & 0.25 & 1,025 & 93.2 \\
2 & 0.30 & 1,025 & 93.2 \\
\hline
\end{tabular}

手法 A， B，C のいずれかで正解できる件数に基 づく精度 (以下, 「精度の限界值」) は, 閾值が 0.40 , 0.45 のときに最大值 $(94.9 \%)$ を取る。手法 C 単体の 精度 (図 5) は間值が 0.40 で $73.0 \% ， 0.45$ で $73.6 \%$ であるが，この差の $0.6 \%$ に相当する 7 件は手法 A または B で正解できるため精度の限界值は等しい. なお，閾值が 0.20 のとき比べ，閾值が $0.40 ， 0.45$ のときは, (i) 手法 A, B では正解できないが手法 C で正解できるケースが増える。ただし，それと同時 に (ii) 手法 A または B で正解できるが, 手法 Cで は (正解の版よりも編集日時が古い版を) 誤検出す るケースが増えると考えられる。 そのため，(i) に よって精度の限界值は間值が $0.40,0.45$ のときのほ うが高いが, (ii) によって提案手法の精度は 0.20 の ときのほうが高いという結果になると解釈できる.

\section{6 初出時点データセットの構築}

4.5 節の結果を踏まえ, 手法 B の先頭単語数を 5, 手法 C の類似度スコアの閾值を 0.20 に設定し, 提案手法を適用した。

まず，基礎情報データセットでの 181,150 件のペー ジ上の 926,610 件の学術文献を対象に, 初出時点候 補を取得した。手法 A では 923,482 件, 手法 B で は 882,144 件, 手法 Cでは 860,105 件を取得した.

次に, 初出時点候補のうち, 編集日時が最も古い ものを選択することにより，全体の $99.7 \%$ (923,894 件)に対する初出時点を特定した。残る $0.3 \%(2,716$ 件) は，主に 2 つの理由により，いずれの手法でも 初出時点候補を取得できない.すなおち，(1) 他の ページを読み込むことで参照記述を表示させている
場合，ページ本文には直接記述されていないため検 出されない. (2) 2017 年 3 月 1 日時点から見て直近 の編集によって参照記述が追加された場合, ダンプ データに当該編集が含まれていないケースがあり, それらは検出されない.

最後に, 研究分野ごとの初出時点の取得件数を圊 6に 示す. 表 6の「減少数」は DOI リンクの初出時点 データセットからの減少数を示し, 4.3 .1 項で除外 した 193 件と, 前述の 2,716 件の計 2,909 件の内訳 である．以上から，いずれの手法でも初出時点が特 定できないケースは少なく，個別の分野においても 著しい減少は生じていない.

表 6: 研究分野ごとの初出時点の取得件数 $(\mathrm{n}=923,894)$

\begin{tabular}{rrr|rrr}
\hline 分野 & 取得件数 & 減少数 & 分野 & 取得件数 & 減少数 \\
\hline 経済 & 11,525 & 20 & 多領 & 102,139 & 250 \\
社会 & 55,407 & 182 & 神経 & 42,186 & 265 \\
精神 & 40,016 & 166 & 環境 & 22,370 & 59 \\
免疫 & 17,837 & 31 & 化学 & 42,460 & 219 \\
分子 & 105,668 & 299 & 地球 & 32,105 & 197 \\
動植 & 70,433 & 108 & 天体 & 38,543 & 31 \\
微生 & 19,923 & 172 & 数学 & 19,876 & 160 \\
生物 & 90,544 & 165 & 材料 & 5,673 & 10 \\
臨床 & 124,417 & 282 & 物理 & 26,191 & 69 \\
薬学 & 24,914 & 140 & 工学 & 11,198 & 36 \\
農学 & 8,460 & 27 & 計算 & 12,009 & 21 \\
\hline
\end{tabular}

\section{5. 考察}

\section{1 研究分野ごとの精度}

研究分野ごとの手法単体および最終的な精度を瞨 可に 示す。それぞれの研究分野の精度は，50 件のサンプ ルにおいて正解と判定された初出時点候補の割合を 指す。たとえば, 経済学・ビジネスでは, 手法 Aによ り 20 件を正解したため手法 A 単体の精度は $40.0 \%$ である。また,「手法 $\mathrm{A}+\mathrm{B}+\mathrm{C} 」$ は提案手法での精

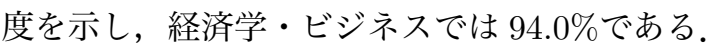

手法単体で見ると, 手法 A では薬学・毒物学が最も 高く $(78.0 \%)$, 経済学・ビジネスが最も低い $(40.0 \%)$. 手法 B では精神学・心理学が最も高く $(94.0 \%)$, 物 理学が最も低い $(68.0 \%)$. 手法 C では免疫学が最 も高く $(86.0 \%)$, 社会科学一般と化学が最も低い 
表 7: 研究分野ごとの手法単体および最終的な精度 $(\%)$

\begin{tabular}{l|ccccccccccc||c}
\hline 条件/分野 & 経済 & 社会 & 精神 & 免疫 & 分子 & 動植 & 微生 & 生物 & 臨床 & 薬学 & 農学 & \\
\hline 手法 A & 40.0 & 50.0 & 42.0 & 70.0 & 72.0 & 66.0 & 66.0 & 64.0 & 70.0 & 78.0 & 72.0 & \\
手法 B & $\mathbf{8 8 . 0}$ & 76.0 & $\mathbf{9 4 . 0}$ & $\mathbf{8 8 . 0}$ & $\mathbf{9 2 . 0}$ & $\mathbf{8 2 . 0}$ & $\mathbf{8 0 . 0}$ & $\mathbf{8 0 . 0}$ & $\mathbf{8 6 . 0}$ & $\mathbf{8 4 . 0}$ & $\mathbf{8 6 . 0}$ & \\
手法 C & 58.0 & 56.0 & $\mathbf{8 0 . 0}$ & $\mathbf{8 6 . 0}$ & $\mathbf{8 2 . 0}$ & 72.0 & 76.0 & 74.0 & 70.0 & 76.0 & 76.0 & \\
\hline 手法 A+B+C & $\mathbf{9 4 . 0}$ & $\mathbf{9 0 . 0}$ & $\mathbf{9 8 . 0}$ & $\mathbf{9 6 . 0}$ & $\mathbf{9 6 . 0}$ & $\mathbf{9 4 . 0}$ & $\mathbf{9 2 . 0}$ & $\mathbf{9 0 . 0}$ & $\mathbf{9 8 . 0}$ & $\mathbf{9 6 . 0}$ & $\mathbf{9 4 . 0}$ & \\
\hline \hline 条件/分野 & 多領 & 神経 & 環境 & 化学 & 地球 & 天体 & 数学 & 材料 & 物理 & 工学 & 計算 & 全体 \\
\hline 手法 A & 74.0 & 62.0 & 58.0 & 70.0 & 60.0 & 76.0 & 44.0 & 70.0 & 60.0 & 62.0 & 58.0 & 62.9 \\
手法 B & $\mathbf{8 8 . 0}$ & $\mathbf{8 6 . 0}$ & $\mathbf{9 0 . 0}$ & 72.0 & $\mathbf{8 4 . 0}$ & $\mathbf{8 8 . 0}$ & $\mathbf{8 6 . 0}$ & $\mathbf{8 2 . 0}$ & 68.0 & $\mathbf{8 8 . 0}$ & $\mathbf{9 2 . 0}$ & $\mathbf{8 4 . 5}$ \\
手法 C & $\mathbf{8 0 . 0}$ & 76.0 & 74.0 & 56.0 & 78.0 & 78.0 & 64.0 & 68.0 & 58.0 & 58.0 & 60.0 & 70.7 \\
\hline 手法 $\mathbf{A + B + C ~}$ & $\mathbf{9 6 . 0}$ & $\mathbf{9 4 . 0}$ & $\mathbf{9 8 . 0}$ & $\mathbf{8 6 . 0}$ & $\mathbf{9 4 . 0}$ & $\mathbf{9 2 . 0}$ & $\mathbf{9 0 . 0}$ & $\mathbf{9 4 . 0}$ & $\mathbf{8 4 . 0}$ & $\mathbf{9 0 . 0}$ & $\mathbf{9 6 . 0}$ & $\mathbf{9 3 . 3}$ \\
\hline
\end{tabular}

精度が $80 \%$ 以上のものは太字，精度が $90 \%$ 以上であるものは網掛けで示している.

(56.0\%). どの分野でも手法 B が最も高いため, 初 出時点において文献夕イトルが示されているケース が多いと考えられる。 また, 手法 A と B の比較で は，いずれの分野でも手法 A の值が低いため，分 野を問わず，文献夕イトルを含む既存の参照記述に 対して後から識別子が付加されるケースが多いと考 えられる。

最終的な精度は, 物理学と化学を除く 20 分野で $90 \%$ 以上である. 值が最も高いのは精神学・心理学, 臨床医学, 環境・エコロジーである (いずれも $98.0 \%$ ). 手法単体と比較すると, どの分野も最終的な精度が 高い，このことから，編集日時が最古の版を選択す ることで手法単体よりも精度が向上する。 20 分野 で $90 \%$ 以上，残る 2 分野でも $80 \%$ 以上であるため, 編集日時が最古の版を選択することにより, 初出時 点を高い精度で特定できる。

\section{2 手法の組み合わせ別の精度}

手法の組み合わせ別の精度を責 8 に示す。「最古 の版を選択時」は提案手法での精度を示す。「限界 值」は，組み合わせに含まれる手法のいずれかで正 解できる件数に基づく精度を示す。たとえば「手法 $\mathrm{A}+\mathrm{B}\lrcorner$ では，手法 $\mathrm{A} ， \mathrm{~B}$ のいずれかで 1,018 件が正 解できるため， $92.5 \%$ となる。

表 8より, 最も值が高い組み合わせは「手法 $\mathrm{A}+\mathrm{B}+\mathrm{C}\lrcorner$ であるため, いずれか 1 つの手法のみで正解できる ものがあり, 精度の向上に貢献している. 2 番目に

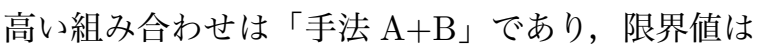
$92.5 \%$, 最古の版を選択時は $91.3 \%$ でる.「手法 $\mathrm{A}+\mathrm{B}+\mathrm{C}\lrcorner$ と比較すると, 手法 $\mathrm{C}$ の追加により值が
表 8: 手法の組み合わせ別の精度 $(\%)$

\begin{tabular}{l|ccc}
\hline 手法の組み合わせ & 限界値 & 最古の版を選択時 & 差 \\
\hline 手法 A のみ & 62.9 & - & - \\
手法 B のみ & 84.5 & - & - \\
手法 C のみ & 70.7 & - & - \\
\hline 手法 A+B & 92.5 & 91.3 & -1.3 \\
手法 B+C & 88.5 & 87.5 & -1.0 \\
手法 A+C & 83.3 & 82.9 & -0.4 \\
手法 A+B+C & 94.8 & 93.3 & -1.5 \\
\hline
\end{tabular}

$2 \%$ ぼ向上するが，手法 C で正解できるものは概 ね手法 $\mathrm{A}$ または $\mathrm{B}$ により正解可能と言える。 3 番

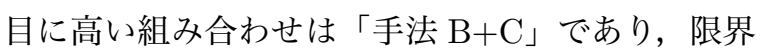
值は $88.5 \%$, 最古の版を選択時は $87.5 \%$ である。手 法 $\mathrm{A}+\mathrm{B}+\mathrm{C}\lrcorner$ と比較すると, 手法 $\mathrm{A}$ の追加により 值が $6 \%$ ほど向上するため, 文献夕イトルを用いた 手法では正解できないが，識別子を用いた手法では 正解できるものが一定数あると言える.

「手法 $\mathrm{A}+\mathrm{B}+\mathrm{C}\lrcorner$ での限界值と最古の版を選択時 の差は $1.5 \%$ である。このことから，1,100 件のうち 17 件は，いずれかの手法で正解できるが，最古の 版を選択することで不正解の候補が適用される。 た だし，この割合は小さいことから，最古の版を選択 する方法は概衩妥当と考えられる。

\section{3 識別子ごとの初出時点候補の取得率}

手法 A に関して, 評価実験ではDOI名, PubMed, Bibcode, alternative id を使用した。分野ごとに, どの識別子が初出時点候補の取得に貢献したかを 
表 9: 各分野での識別子による初出時点候補の取得件数および取得率, 識別子の種別ごとの取得率

\begin{tabular}{l|rrrrrrrrrrr}
\hline 項目/分野 & 経済 & 社会 & 精神 & 免疫 & 分子 & 動植 & 微生 & 生物 & 臨床 & 薬学 & 農学 \\
\hline 取得件数 & 5,445 & 28,558 & 20,199 & 13,110 & 83,303 & 46,058 & 15,912 & 71,396 & 87,621 & 19,101 & 6,066 \\
取得率 (\%) & 47.2 & 51.5 & 50.5 & 73.5 & 78.8 & 65.4 & 79.9 & 78.9 & 70.4 & 76.7 & 71.7 \\
\hline DOI 名 & 42.9 & 43.9 & 39.9 & 38.6 & 53.5 & 57.9 & 52.6 & 50.0 & 42.6 & 47.0 & 56.3 \\
DOI Suffix & 45.8 & 46.7 & 40.7 & 39.4 & 54.1 & 61.0 & 53.7 & 50.9 & 43.5 & 47.9 & 57.4 \\
PubMed & 0.5 & 9.2 & 18.6 & 58.4 & 66.6 & 8.6 & 51.8 & 62.7 & 51.6 & 55.0 & 27.1 \\
alternative id & 4.2 & 1.7 & 2.3 & 1.4 & 1.3 & 1.6 & 2.4 & 1.3 & 1.3 & 2.0 & 4.7 \\
Bibcode & 0.0 & 0.0 & 0.0 & 0.0 & 0.0 & 0.0 & 0.0 & 0.0 & 0.0 & 0.0 & 0.0 \\
\hline \hline 項目/分野 & 多領 & 神経 & 環境 & 化学 & 地球 & 天体 & 数学 & 材料 & 物理 & 工学 & 計算 \\
\hline 取得件数 & 82,024 & 27,671 & 12,565 & 33,896 & 22,178 & 32,214 & 10,133 & 4,297 & 16,674 & 7,019 & 7,203 \\
取得率 (\%) & 80.3 & 65.6 & 56.2 & 79.8 & 69.1 & 83.6 & 51.0 & 75.7 & 63.7 & 62.7 & 60.0 \\
\hline DOI 名 & 60.1 & 42.0 & 49.1 & 73.2 & 66.0 & 71.3 & 44.1 & 69.8 & 60.7 & 58.2 & 53.8 \\
DOI Suffix & 62.9 & 43.0 & 51.6 & 74.3 & 67.6 & 71.6 & 50.3 & 71.9 & 62.0 & 59.0 & 54.7 \\
PubMed & 48.9 & 45.6 & 8.7 & 11.2 & 0.0 & 0.2 & 0.2 & 4.7 & 1.8 & 1.6 & 8.5 \\
alternative id & 0.0 & 2.4 & 2.3 & 2.1 & 4.0 & 1.1 & 1.2 & 5.5 & 1.4 & 7.4 & 2.5 \\
Bibcode & 2.7 & 0.0 & 0.1 & 0.5 & 2.0 & 60.7 & 0.1 & 1.1 & 7.3 & 0.7 & 0.0 \\
\hline
\end{tabular}

各分野での初出時点候補の取得率が最も高い識別子を網掛けで示している.

考察するために，各分野での識別子による初出時 点候補の取得件数と取得率, 識別子の種別ごとの取 得率を長 9に示す。たとえば, 経済学・ビジネスで は 11,525 件のうち，いずれかの識別子により 5,445 件を取得したため，取得率は $47.2 \%$ となる。取得率 (\%) 以下の行は，各識別子単体での取得率を示す.

表 9 上り, 免疫学, 分子生物学・遺伝学, 生物学・ 生化学, 臨床医学, 薬学・毒物学, 神経科学・行動 科学では PubMed，それら以外の 16 分野ではDOI Suffix の取得率が最も高い. DOI 名と DOI Suffix を比較すると，いずれの分野も DOI Suffix の值が 高い.この差が最も大きいのは数学 $(6.2 \%)$ であり, 該当ケースの確認結果, 主に JSTOR の識別子の記 述にDOI Suffix が含まれていた。したがって, DOI 名のみでなく DOI Suffix や PubMed を用いること は, より多くの初出時点候補の取得に有効である.

その他, alternative id は, どの分野も $10 \%$ 未満 であるため, 候補の取得にあまり大きく貢献しない ことが示唆される. Bibcode は天体科学での值が高 く $(60.7 \%)$, 同分野において Bibcodeのみで候補を 取得したものは 4,497 件あり, 取得件数を $14.0 \%$ 増 加させている。 このことから, alternative id は分 野を問わずあまり貢献しない一方, Bibcode は天体 科学分野を対象とする場合には有効と考えられる.

\section{4 文献タイトルの先頭 5 単語での照合}

評価実験では, 手法 B での文献タイトルの先頭 単語数を 5 とした。この設定に関して考察を行う.

1,100 件のサンプルのうち, 文献タイトル全体と 先頭 5 単語の両方で 971 件の初出時点候補を取得 し, うち正解は 868 件である. 先頭 5 単語のみに より 76 件の候補を取得し, うち正解は 62 件であ る.したがって, 精度は, 文献夕イトル全体のみで は $78.9 \%$, 先頭 5 単語を併用すると $84.5 \%$ であるた め, 先頭 5 単語の併用は精度の向上に有効である.

\section{5 手法 C での抽出対象ごとの精度}

手法 Cでは，参照記述として，(a) < ref > タグ で囲まれた脚注と，(b) 名称が Cit で始まるテンプ レートを用いた記述の 2 種類を対象に文献夕イトル を抽出し, 基礎情報データセットの文献タイトルと の文字列間の類似度スコアに基づき初出時点候補の 取得を行った.

本節では，(a)，(b) の 2 種類の対象を用いたこ との精度への影響を考察する. 類似度スコアの閾値 が 0.20 のときの抽出対象ごとの精度を圊 10 に示す. ここではサンプルにおいて初出時点候補とした版に 含まれる当該の参照記述を「(a)のみ」,「(b)のみ」, 
「(a) と (b) の両方」,「その他」に分類し，それぞれ の件数を正解, 不正解の内訳とともに示している. たとえば, 「(a)のみ」は圊 2の例 2 のような記述を 当該文献の初出時点として検出したケースが 804 件 あり，そのうち 614 件が正解であったことを示す。 このとき，精度は合計に対する正解数の割合を指し， $76.4 \%$ である。 なお，その他は初出時点候補を検出 できないケースが 66 件あったことを示す.

表 10 より，正解数は (a) のみでは 614 件，(b) の みでは 646 件であるため, 初出時点において (a), (b) の一方のみを伴うケースが多いことが分かる. したがって，(a)，(b)の 2 種類を用いることは，明 示的な脚注として示されているものに限らず，ょり 広範な参照記述の検出に貢献し, 手法 $\mathrm{C}$ 全体での 精度の向上に寄与することが分かる.

表 10: 閾値が 0.20 のきの抽出対象ごとの精度

\begin{tabular}{|c|c|c|c|c|}
\hline 抽出対象 & (a) のみ & (b) のみ & 両方 & その他 \\
\hline 正解 & 614 & 646 & 482 & 0 \\
\hline 不正解 & 190 & 232 & 166 & 66 \\
\hline 合計 & 804 & 878 & 648 & 66 \\
\hline 精度 & 76.4 & 73.6 & 74.4 & 0.0 \\
\hline
\end{tabular}

\section{6 失敗分析}

\section{（1）いずれの手法でも正解できないケース}

带 8 での「手法 $\mathrm{A}+\mathrm{B}+\mathrm{C} 」$ の限界值より，いずれ かの手法で正解できるケースは $94.8 \%$ である。逆に, 残る $5.2 \%$ に相当する 57 件は，いずれの手法でも正 解できず，その失敗は以下の 4 つに分類できる.

分類 1 文献夕イトルも識別子も記述されていない (24 件)

分類 2 文献夕イトルによる照合の失敗 (23 件)

分類 3 識別子による照合の失敗 (6 件)

分類 4 その他 (4 件)

分類 1 では, 著者名, 雑誌名, 年, 巻・号, ページ なぞが記述されているケースが 19 件，URI のみの 記述が 4 件, URI と雑誌名のみの記述が 1 件あった.

分類 2 では，文献夕イトルが大きく異なるものが 10 件, 入力詋りや単語の抜けなどがあるものが 13 件あった。具体的には, Paper Title はドイツ語だ が Ref Title は英語であるものや，Crossref のメ夕
データ上の Paper Title と当該コンテンツにアクセ スした際の文献夕イトルが異なるものなどがあった。 分類 3 では, 対応外の識別子 (CiteSeerX) のみが 書かれているものが 1 件，DOI名に誤りがあるもの が 1 件, PubMed の識別子は書かれているが DOI 名との対応関係が取得できないものが 4 件あった。

分類 4 では, 参照記述ではない要素を誤検出した ケースが 2 件, 2017 年 3 月 1 日時点から見て直近 の編集で追加されているものの, 当該の版がダンプ データに含まれていないケースが 2 件あった。

以上から, 識別子と文献夕イトルを用いて特定可 能なものは概ね正確に特定できたと評価できる。失 敗ケースのうち, 分類 3 での PubMed と DOI 名の 対応関係が取得できていないことによる失敗は解消 可能と考えられるため, 更に精度の向上を図る場合 には優先的に取り組む課題として位置付けられる。

5.1 節で示したように，分野ごとに比較すると， 化学と物理学の精度が比較的低い. いずれの手法で も正しい初出時点が取得できないケースは, 化学, 物理学ともに 7 件である。その内訳として，化学で は分類 1 が 6 件, 分類 2 が 1 件であり, 物理学では 分類 1 が 3 件, 分類 2 が 3 件, 分類 4 が 1 件であ る.このことから, 化学では初出時点において文献 タイトルと識別子がいずれも示されていないために 精度が低い. 物理学では, 同様の理由に加え, 文献 タイトルが一致しないために精度が低いと言える。

\section{（2）最古の版を選択することによる失敗}

表 8での「手法 $\mathrm{A}+\mathrm{B}+\mathrm{C} 」$ の差より，いずれかの 手法で正解できるが，最古の版を選択することによ り不正解となるものは $1.5 \%$ (17 件) である。 その 内訳を圊 11に示す。「初出時点候補が正解である手 法」は, 候補が正解と判定された手法を示す。「最古 の版を選択時に適用される手法」は, 最古の版を取 得した手法, かつ, その候補が不正解であるものを 示す. たとえば, 件数が 8 件のケースでは, 手法 $\mathrm{A}$, Cで正解できるが，手法 Bでの候補が最古の版，か つ, 不正解のケースである.

表 11から，最古の版を選択することによる失敗 のうち，15 件が手法 A， 1 件が手法 B，10 件が手 法 Cで正解可能である. 逆に, 最古の版, かつ, 不 正解の候補を取得したケースは，2 件が手法 A， 16 件が手法 B，6 件が手法 C によるものである。この ことから，主に手法 $\mathrm{A}, \mathrm{C}$ で正解可能なものにおい て, 手法 Bでの不正解の候補が選択された結果, 失 
表 11: 最古の版を選択することによる失敗の内訳

\begin{tabular}{llr}
\hline $\begin{array}{l}\text { 初出時点候補が } \\
\text { 正解である最古の版を選択時に }\end{array}$ & 件数 \\
\hline 手法 A, $\mathrm{A}$ đ C & 手法 B & 8 \\
手法 A & 手法 B, C & 5 \\
手法 C & 手法 A, B & 2 \\
手法 A & 手法 B & 1 \\
手法 A, B & 手法 C & 1 \\
\hline
\end{tabular}

敗していることが分かる.

\section{7 初出時点の特定精度の比較}

提案手法と，筆者ら [8]によるDOI リンクの初 出時点の特定手法 (以下, 「DOI リンク手法」) の精 度の比較を表 12に示す。両者ともに, サンプルの 抽出条件は無作為抽出であり, サンプル数は各分野 50 件ずつの計 1,100 件である，全体での精度は，提 案手法が $93.3 \%$, DOI リンク手法が $36.2 \%$ である.

表 12 から, 提案手法により, 全分野で大幅に精度 が向上した。また，DOIリンク手法は分野ごとにば らつきがみられるが, 提案手法は化学と物理学がや や低いものの，分野を問わず概ね高い值と言える.

\section{6. 結論と今後の課題}

本研究では, ある観察時点で残存する学術文献の 参照記述を追加した編集を特定する手法を構築し, その精度の評価を行った。

提案手法は，まず，Wikipediaのテキスト群から 参照記述を抽出し, その書誌情報を学術文献デー夕 ベースと照合することで基礎情報データセットを構 築する. 次に, ページ情報を用いたダンプデータと の照合により, 当該ページの編集履歴と本文デー夕 群を取得する.さらに, 基礎情報データセットから 文献夕イトルと識別子を抽出し, 本文デー夕群に対 して識別子または文献タイトルを用いた手法 A，B， $\mathrm{C}$ を適用することで初出時点候補 $\mathrm{A}, \mathrm{B}, \mathrm{C}$ を取得 する. 最後に, 編集日時が最古のものを選択するこ とにより初出時点データセットを構築する.

評価実験では，2017 年 3 月 1 日時点での英語版 の DOI リンクの初出時点データセットを基に構築 した基礎情報データセットを使用した。実験条件と して, 手法 B での文献タイトルの先頭単語数は 5 ,
手法 Cでの文献夕イトル間の類似度スコアの閾值は 0.20 とした. また, DOI Suffix, PMID, PMCID, Bibcode, alternative id を追加取得した。そのうえ で, 提案手法を適用し, 各分野から無作為抽出した サンプルに対する初出時点候補の正誤判定を行った。 評価実験の結果，まず，精度は，全体で $93.3 \%$, 20 分野で $90 \%$ 以上，残る 2 分野で $80 \%$ 以上である. このことから，分野を問わず概ね高い精度で初出時 点を特定可能であることを示した. さらに, 手法単 体では，文献夕イトルによる照合を行う手法 B の 精度が最も高いことを明らかにした。

次に, 文献夕イトル全体に加えて先頭 5 単語を 使用することや，識別子を併用することが精度の 向上に有効である点を示した。 また, 初出時点候補 から編集日時が最古のものを選択する方法が概ね 妥当であることを示した。 その他, 識別子による候 補の取得では, 多くの分野でDOI Suffix, PMID, PMCID が特に有効であることや, 天体科学分野で はBibcode が有効と考えられることを示した。

他方で, 失敗分析を通じて, いずれの手法でも正 しい初出時点を取得できないケースを，(1) 文献夕 イトルも識別子も記述されていない，(2) 文献夕イ トルによる照合の失敗，(3) 識別子による照合の失 敗，(4) その他に分類した。なお，(3) に関しては DOI 名と PMID および PMCID の対応関係の取得 を改善することで解消可能なものが一部含まれるが, 識別子と文献夕イトルによって初出時点が特定可能 なものは概ね正確に特定することができた。

最後に, 筆者らが過去に提案した DOI リンクを 用いた特定手法と, 提案手法との比較により, すべ ての分野で精度が大幅に向上したことを示した。

本研究の貢献は次の 3 点である. 任意の観察時点 で残存する参照記述について，(1) 識別子と文献夕 イトルを手がかりとすることで，分野を問わず概秝 高い精度で初出時点を特定可能であることを明らか にした. (2) 先行研究における特定の方法論に大き く依存せず，沉用的に適用可能な手法を示した。 ま た，人間による手作業の介在をほとんど要さずに自 動処理可能な手法を示した. (3) 不完全な記述や誤 りが含まれるために特定が容易でないなどの障壁に より，これまでほとんど明らかにされてこなかった Wikipedia 上での参照記述の追加という事象を解明 するうえで重要な基盤となる方法論を構築した。

今後の課題は, (1) 英語版以外の言語版への手法 の適用と精度の評価，(2) 異なる種別のコンテンッ 
表 12: 提案手法とDOI リンク手法での精度の比較 (\%)

\begin{tabular}{l|ccccccccccc||c}
\hline 項目/分野 & 経済 & 社会 & 精神 & 免疫 & 分子 & 動植 & 微生 & 生物 & 臨床 & 薬学 & 農学 & \\
\hline 提案手法 & 94.0 & 90.0 & 98.0 & 96.0 & 96.0 & 94.0 & 92.0 & 90.0 & 98.0 & 96.0 & 94.0 & \\
DOI リンク手法 & 34.0 & 40.0 & 32.0 & 30.0 & 52.0 & 40.0 & 36.0 & 34.0 & 20.0 & 38.0 & 32.0 & \\
\hline \hline 項目/分野 & 多領 & 神経 & 環境 & 化学 & 地球 & 天体 & 数学 & 材料 & 物理 & 工学 & 計算 & 全体 \\
\hline 提案手法 & 96.0 & 94.0 & 98.0 & 86.0 & 94.0 & 92.0 & 90.0 & 94.0 & 84.0 & 90.0 & 96.0 & $\mathbf{9 3 . 3}$ \\
DOI リンク手法 & 54.0 & 26.0 & 28.0 & 30.0 & 38.0 & 48.0 & 28.0 & 52.0 & 38.0 & 42.0 & 24.0 & $\mathbf{3 6 . 2}$ \\
\hline
\end{tabular}

に対する手法の適用と精度の評価，(3) 初出時点デー タセットを用いた編集および編集者の分析である. (1) に関しては，言語版を問わず沉用的に適用可能 であるかを明らかにする。(2) に関しては，たとえ ば学術書を対象とした場合の実験条件や，参照先の 判定に用いる外部データベースの検討を行ったうえ での適用と評価を行う。(3) に関しては，いつ頃か ら, どれだけの参照記述が追加されてきたかに加え， それらの経年変化の分析を行う。また，編集者に関 しても同様の分析を行う.さらに, 編集者ごとの追 加件数の偏りや占有状況の分析を通じて, 参照記述 の持続性や安定性の問題の有無の解明に取り組む.

\section{謝辞}

本研究の一部は，科学研究費補助金基盤研究 (C) (課題番号: 17K00449)「ブラウジング型探索タスク の解明とその支援手法に関する研究」, 同基盤研究 (C) (課題番号: 17K00448)「サイエンスリンケージ の分野横断性に着目した論文・特許間引用の分析」 の助成によって行われたものである。

\section{参考文献}

[1] Bilder, Geoffrey: "Geoffrey Bilder: Strategic Initiatives Update \#crossref15", 2015. https://www.slideshare.net/CrossRef/ geoffrey-bilder-crossret15（2019 年 12 月 31 日参照).

[2] Wikimedia Foundation: "Wikimedia project at a glance". https://stats.wikimedia. org/EN/SummaryEN.htm (2019 年 12 月 31 日 参照).

[3] Alexa Internet, Inc.: "Alexa Top 500 Global Sites". https://www.alexa.com/topsites (2019 年 7 月 1 日参照).

[4] 日下九八: 「ウィキペディア：その信頼性と 社会的役割」，情報管理，Vol. 55, No. 1, pp. 2-12, 2012. https://doi.org/10.1241/ johokanri.b5.2.

[5] Mesgari, Mostafa; Okoli, Chitu; Mehdi, Mohamad; Nielsen, Finn Årup; Lanamäki, Arto: " "The sum of all human knowledge": A systematic review of scholarly research on the content of Wikipedia", Journal of the Association for Information Science and Technology, Vol. 66, No. 2, pp. 219-245, 2014. https://doi.org/10.1002/asi.23172.

[6] Nielsen, Finn Årup: "Scientific citations in Wikipedia", First Monday, Vol. 12, No. 8, 2007. https://doi.org/10.5210/fm. v1218.1997.

[7] Pooladian, Aida; Borrego, Ángel: "Methodological issues in measuring citations in Wikipedia: a case study in Library and Information Science", Scientometrics, Vol. 113, No. 1, pp. 455-464, 2017. https://doi.org/ $10.1007 / \mathrm{s} 11192-017-2474-\mathrm{z}$.

[8] 吉川次郎; 高久雅生; 芳鐘冬樹: 「DOI リン クに基づくWikipedia 上の参照記述における 編集者の分析」，情報知識学会誌，Vol. 30, No. 1, pp. 21-41, 2020. https://doi.org/ 10.2964/jsik_2020_004.

[9] Halfaker, Aaron: $\ulcorner$ mwcites $\cdot \mathrm{PyPI}\lrcorner$. https: //pypi.org/project/mwcites/ (2019 年 12 月 31 日参照).

[10] 相澤彰子; 大山敬三; 高須淳宏; 安達淳: 「レ コード同定問題に関する研究の課題と現状」, 電子情報通信学会論文誌. D-I, 情報・システム, I-情報処理, Vol. 88, No. 3, pp. 576-589, 2005.

[11] McVeigh, Marie E.: "Citation Indexes and the Web of Science", Encyclopedia of Library and Information Sciences, Third Edition, pp. 1027-1037, 2009. https://doi. org/10.1081/e-elis3-120044569.

[12] Abdulhayoglu, Mehmet Ali; Thijs, Bart; Jeuris, Wouter: "Using character n-grams to match a list of publications to references in bibliographic databases", Scientometrics, Vol. 109, No. 3, pp. 1525-1546, 2016. https: //doi.org/10.1007/s11192-016-2066-3.

[13] Lawrence, Steve; Giles, C. Lee; Bollacker, Kurt: "Digital Libraries and $\mathrm{Au}-$ tonomous Citation Indexing", Computer, Vol. 32, No. 6, pp. 67-71, 1999 . https: //doi.org/10.1109/2.769447. 
[14] Lee, Dongwon; Kang, Jaewoo; Mitra, Prasenjit; Giles, C. Lee; On, Byung Won: "Are your citations clean?", Communications of the ACM, Vol. 50, No. 12, pp. 33-38, 2007. https://doi.org/10.1145/1323688. 1323690.

[15] Khan, Samiya; Liu, Xiufeng; Shakil, Kashish A.; Alam, Mansaf: "A survey on scholarly data: From big data perspective", Information Processing \&ु Management, Vol. 53, No. 4, pp. 923-944, 2017. https: //doi.org/10.1016/j.ipm.2017.03.006.

[16] Kan, Min-Yen: "ParsCit: An open-source CRF Reference String and Logical Document Structure Parsing Package". https: //parscit.comp.nus.edu.sg/ (2019 年 12 月 31 日参照).

[17] Councill, Isaac; Giles, C. Lee; Kan, MinYen: "ParsCit: an Open-source CRF Reference String Parsing Package", Proceedings of the Sixth International Conference on Language Resources and Evaluation (LREC'08), pp. 661-667. European Language Resources Association (ELRA), 2008. http://www.lrec-conf .org/proceedings/ 1rec2008/pdf/166_paper.pdf.

[18] "CiteSeerX". http://citeseerx.ist.psu. edu/index (2020 年 1 月 15 日参照).

[19] Williams, Kyle; Choudhury, Sagnik ray: "CiteSeerX Software". http://csxstatic. ist.psu.edu/downloads/software (2019 年 12 月 28 日参照).

[20] Cortez, Eli; Silva, Altigran S.da ; Gonçalves, Marcos André; Mesquita, Filipe; Moura, Edleno S.de : "FLUX-CIM: Flexible Unsupervised Extraction of Citation Metadata", Proceedings of the 7th ACM/IEEE-CS Joint Conference on Digital Libraries, JCDL '07, pp. 215-224. ACM, 2007.

[21] Peng, Fuchun; McCallum, Andrew: "Information extraction from research papers using conditional random fields", Information Processing \&6 Management, Vol. 42, No. 4, pp. 963-979, 2006. https://doi.org/10.1016/ j.ipm.2005.09.002.

[22] Ororbia, Alexander G., II; Wu, Jian; Khabsa, Madian; WIlliams, Kyle; Giles, Clyde Lee: "Big Scholarly Data in CiteSeerX: Information Extraction from the Web", Proceedings of the 24th International Conference on World Wide Web, WWW'15 Companion, pp. 597-602. ACM, 2015. https: //doi.org/10.1145/2740908.2741736.

[23] Prasad, Animesh; Kaur, Manpreet; Kan, Min-Yen: "Neural ParsCit: a deep learning-based reference string parser", International Journal on Digital Libraries, Vol. 19, No. 4, pp. 323-337, 2018. https: //doi.org/10.1007/s00799-018-0242-1.
[24] Teplitskiy, Misha; Lu, Grace; Duede, Eamon: "Amplifying the impact of open access: Wikipedia and the diffusion of science", Journal of the Association for Information Science and Technology, Vol. 68, No. 9, pp. 2116-2127, 2016. https://doi. org/10.1002/asi.23687.

[25] 佐藤翔; 吉田光男; 逸村裕:「Wikipedia 日本 語版からの学術論文の引用状況」, 日本図書館 情報学会春季研究集会発表論文集, pp. 81-84, 2013.

[26] Kikkawa, Jiro; Takaku, Masao; Yoshikane, Fuyuki: "DOI Links on Wikipedia", Proceedings of the 18th International Conference on Asia-Pacific Digital Libraries (ICADL 2016), pp. 369380, 2016. https://doi.org/10.1007/ 978-3-319-49304-6_40.

[27] Thelwall, Mike: "Does Astronomy research become too dated for the public? Wikipedia citations to Astronomy and Astrophysics journal articles 1996-2014", El Profesional de la Información, Vol. 25, No. 6, pp. 893900, 2016. https://doi.org/10.3145/epi. $2016 . n o v .06$.

[28] Kousha, Kayvan; Thelwall, Mike: "Are wikipedia citations important evidence of the impact of scholarly articles and books?", Journal of the Association for Information Science and Technology, Vol. 68, No. 3, pp. 762-779, 2017. https://doi.org/10.1002/ asi.23694.

[29] Lin, Jennifer; Fenner, Martin: "An analysis of Wikipedia references across PLOS publications", 2014. https://doi.org/10.6084/ m9.tigshare.1048991.v3 (2019 年 12 月 31 日参照).

[30]「ウィキテキスト - MediaWiki」. https: //wWw.mediawiki.org/wiki/Wikitext/ja (2020 年 1 月 15 日参照).

[31]「Wikipedia:出典テンプレート - Wikipedia」. https://ja.wikipedia.org/w/index.php? tit $\perp e=W P: C I$ (2020 年 1 月 15 日参照).

[32] PLOS: "ALM". https://alm.plos.org/ (2020 年 1 月 15 日参照).

[33] "User:Citation bot - Wikipedia". https://en.wikipedia.org/wiki/User: Citation_bot (2019 年 12 月 31 日参照).

[34] Smith, Martin R.: "ms609/citation-bot". https://github.com/ms609/citation-bot (2019 年 12 月 31 日参照).

[35] 中村晃; 鈴木優; 石川佳治:「共同執筆コンテ ンツにおける単語の起源追跡」, 情報処理学会 論文誌データベース (TOD), Vol. 8, No. 2, pp. 43-56, 2015. http://id.nii.ac.jp/1001/ $00142566 /$.

[36] Wikimedia Foundation: "Wikimedia Downloads". https://dumps.wikimedia.org/ backup-index.htm】 (2019 年 12 月 1 日参照). 
[37] Gusfield, Dan: "Algorithms on Strings, Trees, and Sequences: Computer Science and Computational Biology". Cambridge University Press, 1997. https://doi.org/10.1017/ cho.9780) $115 / 4931$.

[38] Levenshtein, V. I.: "Binary codes capable of correcting deletions, insertions, and reversals", Soviet Physics-Doklady, Vol. 10, No. 8, pp. 707-710, 1966.

[39] "Self-determination theory - Wikipedia". https://en.wikipedia.org/w/index.php? oldid=332b22310 (2009 年 12 月 8 日 17 時 37 分時点の版, 2020 年 1 月 15 日参照).

[40] Frodi, Ann; Bridges, Lisa; Grolnick, Wendy: "Correlates of Mastery-Related Behavior: A Short-Term Longitudinal Study of Infants in Their Second Year", Child Development, Vol. 56, No. 5, pp. 1291-1298, 1985. https: //www.jstor.org/stable/1130244.

[41] Crossref: "Crossref REST API". https:// api.crossref.org/ (2019 年 12 月 31 日参照).

[42] Clarivate Analytics: "InCites Essential Science Indicators", 2019. https://esi. clarivate.com/ (2019 年 12 月 31 日参照).

[43] Clarivate Analytics: "Journal List (InCites Essential Science Indicators Help)". http://help.incites.clarivate.com/ incitesLiveESI/ESIGroup/overviewESI/ esi.Journalsl.ist.html (2019 年 12 月 31 日 参照).

[44] 小野寺夏生：「論文データベースにおける主題 分類一情報分析への利用の視点から一」, 情報の 科学と技術, Vol. 66, No. 6, pp. 272-276, 2016. https://doi.org/10.18919/jkg.66.6_272.
[45] National Center for Biotechnology Information: "APIs - Develop". https://www.ncbi. nlm.nih.gov/home/develop/api/ (2019 年 12 月 31 日参照).

[46] The SAO/NASA Astrophysics Data System: "SAO/NASA ADS HELP: Direct Access". http://ads.nao.ac.jp/abs_doc/ help_pages/linking.html (2019 年 12 月 31 日参照).

[47] Crossref: "Crossref Metadata API JSON Format". https://github.com/CrossRef/ rest-api-doc/blob/master/api_format. md (2019 年 12 月 31 日参照).

[48] "Wikimedia database dump of the English Wikipedia on March 01, 2017 : Wikimedia projects editors : Free Download, Borrow, and Streaming : Internet Archive". https://archive.org/details/ enwiki-20170301 (2019 年 12 月 31 日参照).

[49]「Help:差分 - Wikipedia」. https://ja. wikipedia.org/w/index.php?title $=\mathrm{H}$ : DIFF (2020 年 1 月 15 日参照).

[50] Lawrence, Miles B.; Pelissier, Joseph M.: "Atlantic Hurricane Season of 1981", Monthly Weather Review, Vol. 110, No. 7, pp. $852-866, \quad 1982$. //doi.org/10.1175/1520-0493(1982) $110 \% 3 \mathrm{C} 0852 \% 3 \mathrm{AAHSO} \% 3 \mathrm{E} 2.0 . \mathrm{CO} \% 3 \mathrm{~B} 2$.

$\begin{array}{ll}\text { (2020年 1月23日 } & \text { 受付) } \\ \text { (2020年 6月 9日 } & \text { 採択) } \\ \text { (2020年 7月 10日 } & \text { J-STAGE早期公開) }\end{array}$

